\title{
Resolution of Common Questions in MDL Proceedings
}

\author{
Douglas G. Smith*
}

\section{INTRODUCTION}

Multidistrict litigation procedures have grown in significance as an important tool for resolving large-scale litigation. Indeed, in recent years, various reports have noted that from one third to one half of all cases in the federal courts are part of MDL proceedings. ${ }^{1}$ From the defendants' perspective, consolidation in a federal MDL proceeding may make nationwide litigation more manageable. From a plaintiff's perspective, consolidating the litigation in an MDL proceeding may increase the pressure on defendants to enter into a global settlement of the asserted claims. Thus, both defendants and plaintiffs may have reasons to support creation of an MDL proceeding.

Nonetheless, in recent years as their use has grown, MDL proceedings have been the subject of increasing criticism. Defendants in certain MDL proceedings have felt pressured to settle claims of dubious merit. Moreover, as aggregate litigation of this sort increases, there is an incentive for plaintiffs' counsel to include more and more claims that are not meritorious, in order to increase their own fees and influence in the

\footnotetext{
* Partner, Kirkland \& Ellis LLP. J.D., Northwestern University School of Law; M.B.A., The University of Chicago; B.S./B.A., State University of New York at Buffalo. The views expressed in this article are solely those of the author and do not necessarily represent those of Kirkland \& Ellis LLP or its clients. The author was counsel of record on behalf of defendants in the Heparin and Meridia MDL proceedings discussed herein.

1. See, e.g., Andrew D. Bradt \& D. Theodore Rave, The Information-Forcing Role of the Judge in Multidistrict Litigation, 105 CALIF. L. REV. (forthcoming 2017) (manuscript at 3) ("[C]urrently almost half of the civil cases pending in the federal courts are part of an MDL."), https://papers.ssrn.com/sol3/papers.cfm?abstract_id=2828461; Andrew D. Bradt, The Shortest Distance: Direct Filing and Choice of Law in Multidistrict Litigation, 88 NOTRE DAME L. REV. 759, 784 (2012) ("Recent empirical work by the Federal Judicial Center reveals that one third of all civil cases in the federal courts right now are part of a pending MDL."); U.S. CHAMBER INST. FOR LEGAL REForm, MDL ProceEdings: Eliminating THE ChAFF, 1, 24 n.2 (2015) [hereinafter "U.S. CHAMBER"] ("More than one-third of the civil cases pending in the nation's federal courts are now consolidated in multidistrict litigations . . .."), http://www.instituteforlegalreform.com/uploads/ sites/1/MDL Proceedings web.pdf; Duke L. CTR. FOR Jud. STUD., STANDARDS AND BeST PRACTICES FOR LARGE AND MASS-TORT MDLs xi (2014), https://law.duke.edu/sites/default/ files/centers/judicialstudies/standards_and_best_practices_for_large_and_mass-tort_mdls.pdf ("MDLs represented $45.6 \%$ of the pending civil cases as of June 2014.").
} 
proceedings. $^{2}$ With aggregation comes the risk that individual claims may receive less scrutiny, which may increase the risk that non-meritorious claims receive compensation.

Such sentiments have led to proposals for reform of MDL practice. The proposed Fairness in Class Action Litigation Act of 2017, for example, includes proposed reforms to MDL procedures in addition to reforms designed to curb class action abuses. ${ }^{3}$ Among other things, the Act would require plaintiffs in MDL proceedings to provide evidence of their alleged injury within forty-five days of their case being transferred to a multidistrict proceeding. ${ }^{4}$ It would prohibit trials in multidistrict proceedings unless "all parties to that civil action consent." And it would increase interlocutory appellate involvement in the MDL by providing appellate jurisdiction over orders that "may materially advance the ultimate termination of one or more civil actions in the proceedings." These provisions and others are designed to "diminish abuses in class action and mass tort litigation that are undermining the integrity of the U.S. legal system."7

However, despite the criticisms and calls for reform of the MDL process, courts and litigants have utilized the existing multidistrict procedures to effectively and efficiently resolve cases formerly spread among multiple jurisdictions, both state and federal. These procedures have avoided duplicative effort, resulted in the more expeditious resolution of litigation, and in general increased judicial efficiency. On balance, for litigation that meets the requisite criteria, MDL procedures have proven to be a beneficial tool to advance the efficient resolution of litigation that otherwise might defy easy resolution. Indeed, the criteria for creating an MDL proceeding were created with this goal in mind: to identify those proceedings that might benefit in terms of increased

2. See, e.g., In re Mentor Corp. Obtape Transobturator Sling Prods. Liab. Litig., No. 4:08-MD2004, 2016 WL 4705827, at *1 (M.D. Ga. Sept. 7, 2016) (Mem.) (“[T]he Court had to waste judicial resources deciding motions in cases that should have been dismissed by plaintiff's counsel earliercases that probably should never have been brought in the first place. Enough is enough."); U.S. CHAMBER, supra note 1, at 1 ("MDL proceedings are morphing from a procedural device that is intended to create efficiencies in civil litigation (particularly pretrial discovery) into lawsuit magnets. ... [B] ecause multidistrict proceedings by design have tended to prioritize global issues over individual ones, plaintiffs' counsel have successfully warehoused meritless claims and shielded them from judicial scrutiny in a way they never could if all cases were being tried individually.").

3. Fairness in Class Action Litigation Act of 2017, H.R. 985, 115th Cong. (2017).

4. Id. $\S 105$ (section (i) to the proposed amendment to 28 U.S.C. $\S 1407$ ).

5. Id. (section (j) to the proposed amendment to 28 U.S.C. $\S 1407$ ).

6. Id. (section (k)(1) to the proposed amendment to 28 U.S.C. $\S 1407)$.

7. Id. $\S 102(2)$. 
efficiency from the consolidation of pretrial proceedings in a single federal jurisdiction.

This article addresses one particular aspect of MDL procedures - the use of MDL proceedings to resolve common issues of fact or law that may be dispositive for the entire litigation or certain categories of claims. The article presents evidence demonstrating that this has been one of the most effective aspects of MDL litigation in terms of bringing litigation to a close and effectively and fairly resolving claims. Where litigants have taken advantage of these procedures, a number of MDL proceedings have been significantly narrowed or entirely resolved through summary judgment or other proceedings on common issues central to the litigation. The full implementation of such procedures can only further the MDL process as an effective means of resolving large-scale, complex litigation.

Part II discusses general MDL procedures, including the standards governing MDL consolidation and the procedures that MDL courts have developed to manage and resolve complex litigation. The statute establishing the Judicial Panel on Multidistrict Litigation imposes certain criteria that must be met in order to establish an MDL proceeding. Those criteria explicitly include the existence of "common issues" among the cases that will be part of the MDL proceeding. Thus, the statutory framework specifically contemplates that the MDL process may be utilized to efficiently address common issues, which may be dispositive of all or certain categories of claims.

Part III discusses several examples in which MDL courts have significantly advanced the resolution of litigation by resolving such common issues that cut across the litigation or significant categories of claims. In some instances, nationwide litigation has been completely resolved through such procedures. In other instances, such procedures have served to better define the litigation and the categories of claims that are more or less viable, facilitating resolution through settlement or through further litigation of the remaining claims.

Part IV discusses some ways in which these procedures might be further enhanced. By coordinating the resolution of these common issues with state courts that may have satellite litigation outside of the MDL proceeding and rigorously applying the standards for evaluating scientific evidence where applicable, for example, additional benefits may be achieved. In addition, the scheduling of motion practice and discovery may be phased in order to obtain additional efficiencies, potentially avoiding unnecessary expense and effort by the parties involved in the proceedings. Finally, resolution of common issues may be coupled with individualized review of claims to weed out weak or frivolous claims and further narrow the litigation. 


\section{THE MDL FRAMEWORK}

In 1968, Congress passed the act establishing the Judicial Panel on Multidistrict Litigation (the "Panel") to consider motions to consolidate federal cases filed in multiple jurisdictions for the limited purpose of coordinated pretrial proceedings before a single judge. ${ }^{8}$ The Panel is comprised of sitting federal judges who meet approximately once every two months to consider motions to establish MDL proceedings and to transfer newly-filed cases to existing MDL proceedings. ${ }^{9}$

The statute lays out the criteria that must be satisfied in order for an MDL proceeding to be established. Among other things, transfer of pending cases to a single district for pretrial proceedings is only appropriate when: (1) the actions "involv[e] one or more common questions of fact," (2) the "transfer[] . . will be for the convenience of parties and witnesses," and (3) the transfer "will promote the just and efficient conduct of such actions." 10 The proponent of transfer generally bears the burden to demonstrate that these factors are met. ${ }^{11}$

Panel decisions have provided further guidance regarding the types of cases that may be appropriate for pretrial consolidation. For example, where there are only a minimal number of actions sought to be transferred, the burden on the proponent of transfer is heightened. ${ }^{12}$ Where there are only a couple related cases, MDL consolidation may not be appropriate because the potential inconvenience to the parties from consolidation may outweigh the efficiencies achieved through consolidation. Cooperation among the courts presiding over these related cases may be preferable to consolidation.

Similarly, where issues that are not common to the cases predominate, creation of an MDL proceeding may not be appropriate. ${ }^{13}$ In Electrolux,

8. Multidistrict Litigation Act, Pub. L. No. 90-296, 82 Stat. 109, 109-10 (1968) (codified as amended at 28 U.S.C. $§ 1407$ (2012)).

9. 28 U.S.C. $§ 1407$ (a), (d); Hon. John G. Heyburn II \& Francis E. McGovern, Evaluating and Improving the MDL Process, Summer 2012, at 26, 27.

10. 28 U.S.C. $\$ 1407$ (a).

11. See In re Chase Inv. Servs. Corp. Fair Labor Standards Act (FLSA) \& Wage and Hour Litig., 908 F. Supp. 2d 1372, 1373 (J.P.M.L. 2012) (Mem.) (citing In re Transocean Ltd. Sec. Litig. (No. II), 753 F. Supp. 2d 1373, 1374 (J.P.M.L. 2010) (Mem.)).

12. In re UBS Fin. Servs., Inc. Wage \& Hour Empl. Practices Litig., 818 F. Supp. 2d 1380, 1381 (J.P.M.L. 2011) (Mem.) ("Where only a minimal number of actions are involved, the moving party generally bears a heavier burden of demonstrating the need for centralization."); In re Scotch Whiskey, 299 F. Supp. 543, 544 (J.P.M.L. 1969) ("[W]here, as here, there are a minimal number of cases involved in the litigation the moving party bears a strong burden to show that the common questions of fact are so complex and the accompanying common discovery so time-consuming as to overcome the inconvenience to the party whose action is being transferred and its witnesses.").

13. See, e.g., In re Electrolux Dryer Prods. Liab. Litig., 978 F. Supp. 2d 1376, 1377 (J.P.M.L. 
for example, the Panel denied a motion seeking to consolidate thirty-three individual actions and two putative class actions for fire-related property damages caused by an alleged common defect in dryers. ${ }^{14}$ The Panel denied the motion after concluding that " $[\mathrm{o}] \mathrm{n}$ the present record, it appears that individualized facts concerning the circumstances of each fire, including installation, repair, and maintenance, will predominate over the common factual issues alleged by plaintiffs." 15 Likewise, in In re Spray Polyurethane Foam Insulation, the Panel rejected a request to centralize eight actions for damages allegedly caused by various insulation products installed in plaintiffs' properties, noting again that voluntary cooperation among the courts and parties would be preferable to consolidation given that "it appears that individualized facts concerning the chemical composition of the different products, the training and practices of each installer, and the circumstances of installation at each residence will predominate over the common factual issues alleged by plaintiffs." 16

Relatedly, where there is little overlap in the defendants in the filed actions, consolidation may be rejected. In In re Ambulatory Pain PumpChondrolysis Products Liability Litigation, for example, the Panel denied a motion for MDL transfer where most, if not all, of the defendants were named in only "a handful" of the actions. ${ }^{17}$ Similarly, consolidation of cases involving defendants who are competitors may be a concern, given the potential for the disclosure of trade secrets or other potentially sensitive business information during discovery. ${ }^{18}$

Frequently, however, the propriety of MDL consolidation will be

2013) (Mem.); In re Spray Polyurethane Foam Insulation Prods. Liab. Litig., 949 F. Supp. 2d 1364, 1364 (J.P.M.L. 2013) (Mem.); see also In re Yellow Brass Plumbing Component Prods. Liab. Litig., 844 F. Supp. 2d 1377, 1379 (J.P.M.L. 2012) (Mem.) (denying centralization where "significant localized intervening causation issues [were] expected"); In re Ambulatory Pain-Pump Chondrolysis Prods. Liab. Litig., 709 F. Supp. 2d 1375, 1377 (J.P.M.L. 2010) (citing both product differences and the plaintiffs" "different medical histories" in denying centralization); In re Children's Pers. Care Prods. Liab. Litig., 655 F. Supp. 2d 1365, 1366 (J.P.M.L. 2009) (Mem.) (denying centralization where lawsuits involved "[m]ore than ten different baby products with differing formulations"); In re Victoria's Secret Undergarments/Intimate Apparel Prods. Liab. Litig., 626 F. Supp. 2d 1349, 1350 (J.P.M.L. 2009) (Mem.) (denying centralization because the multiple products will cause discovery to "vary among the actions").

14. Electrolux, 978 F. Supp. 2d at 1376.

15. Id. at 1377 .

16. In re Spray Polyurethane Foam Insulation, 949 F. Supp. 2d at 1364.

17. In re Ambulatory Pain Pump-Chondrolysis, 709 F. Supp. 2d at 1377.

18. See, e.g., In re Yellow Brass Plumbing, 844 F. Supp. 2d at 1378 ("[W]e are typically hesitant to centralize litigation against multiple, competing defendants which marketed, manufactured and sold similar products."); see also In re Invokana (Canagliflozin) Prods. Liab. Litig., 223 F. Supp. 3d 1345, 1348 (J.P.M.L. 2016) (“'[A] multi-defendant MDL may prolong pretrial proceedings, because of, inter alia, the possible need for separate discovery and motion tracks, as well as the need for additional bellwether trials."). 
undisputed. As noted above, both plaintiffs and defendants may have incentives to seek the creation of an MDL proceeding. Moreover, the situations in which the statutory criteria are met may be relatively obvious. Rather, the parties instead may focus their debate upon the proper forum for the MDL proceedings, arguing for fora and specific judges whom they perceive as being more favorable to their position in the litigation. Here, too, the Panel has developed various criteria for determining the most appropriate jurisdiction, such as the convenience and accessibility of the forum, the location of the first-filed case, the location where a majority of actions are pending, the progress of the litigation in each forum, the number of cases in each forum, the parties' preference regarding forum, the experience of the judges presiding over the cases in MDL proceedings, and the ability of the various courts to handle another MDL proceeding. ${ }^{19}$

Nonetheless, as the foregoing discussion makes clear, critical to the establishment of an MDL proceeding is the existence of "common issues" among the cases, warranting consolidation. The common issue requirement does not mean that the cases are appropriate for consolidation for all purposes (including trial) or that procedures such as class certification are warranted. To the contrary, cases in most MDL proceedings are inappropriate for consolidation or for class certification, given the predominance of individualized issues among the various cases that have been filed ${ }^{20}$ and the immature nature of the litigation. ${ }^{21}$

19. Hon. John G. Heyburn II, A View from the Panel: Part of the Solution, 82 Tul. L. REV. 2225, 2239-2240 (2008).

20. Courts have repeatedly rejected attempts to consolidate entire product liability cases for trial on such grounds. See, e.g., In re Consol. Parlodel Litig., 182 F.R.D. 441, 446 (D.N.J. 1998) (rejecting consolidation in pharmaceutical litigation given diverse medical histories and claimed injuries because the "evidence [was] specific and unique to each Plaintiff's case ... [and] it [was therefore] clear that individual issues in these cases w[ould] predominate."); Hasman v. G.D. Searle \& Co., 106 F.R.D. 459, 460 (E.D. Mich. 1985) (refusing to consolidate three product liability cases arising out of plaintiffs' use of intrauterine contraceptive device because individual issues predominated because "[c]onsolidation would make trial confusing, unmanageable and perhaps inequitable"); Janssen Pharmaceutica, Inc. v. Armond, 866 So. 2d 1092, 1098 (Miss. 2004) (reversing trial court order in Propulsid pharmaceutical litigation, citing different fact situations, medical histories, sets of witnesses and testimony, "all in addition to addressing the myriad causation and other products liability issues . .. [that] would unavoidably confuse the jury and irretrievably prejudice the defendants"); Id. at 1101 ("No jury can be expected to reach a fair result under these circumstances, especially concerning an immature tort in which the few cases actually tried suggest that medical evidence about individual causation will be an essential aspect of the case."); see also In re Repetitive Stress Injury Litig., 11 F.3d 368, 373 (2d Cir. 1993) (granting mandamus and vacating order consolidating repetitive stress injury claims given that individual issues outweighed "sole common fact ... [of] a claim of injury of such generality that it covers a number of different ailments for each of which there are numerous possible causes other than the tortious conduct of one of the defendants"); Graziose v. Am. Home Prods. Corp., 202 F.R.D. 638, 641 (D. Nev. 2001) (noting that trial consolidations are particularly problematic "in an area of scientific inquiry such as medicine, where . . scientific and legal controversies are impacted by many individualized circumstances and conditions").

21. For example, consolidation of entire cases for trial is typically inappropriate in cases 
Nonetheless, this requirement does provide a basis for gaining efficiencies through litigation of certain issues that are common among all or certain categories of claims.

Thus, the statutory framework expressly contemplates that one of the benefits of the MDL process is resolution on a consolidated pretrial basis of issues that are common among all or certain categories of the cases that are centralized in the coordinated proceedings. ${ }^{22}$ The resolution of such common issues extends not merely to discovery or other procedural matters, but common substantive issues among the cases. As the Supreme Court has observed,

Congress anticipated that, during the pendency of pretrial proceedings, final decisions might be rendered in one or more of the actions consolidated pursuant to $\S 1407$. It specified that "at or before the conclusion of ... pretrial proceedings," each of the transferred actions must be remanded to the original district "unless [the action] shall have been previously terminated." 23

Indeed, one of the primary efficiencies that the authors of the MDL process sought to gain was the resolution on a common basis of certain dispositive issues that would either narrow or eliminate entirely the aggregate mass of asserted claims. $^{24}$

In recent years, the Panel has underscored the importance of this function of the MDL process. In response to concerns that the creation of

involving mass torts that are not mature. As the Manual for Complex Litigation observes, "[i]n less mature mass tort cases, aggregation decisions may be more difficult and may require the judge to obtain additional information. ... If there are few prior verdicts, judgments, or settlements, additional information may be needed to determine whether aggregation is appropriate." MANUAL FOR COMPLEX Litigation (FourTH) $\S 22.314$ (2004). The Manual defines a mature mass tort as "one that rests on clearly established law and tested and accepted evidence." Id. The Manual explains that:

Litigation is generally considered mature if through previous cases (1) discovery has been thorough, producing a consensus that the available important information has been provided, (2) a number of verdicts have been received indicating the value of claims, and (3) plaintiffs' contentions have been shown to have merit. In a typical mature mass tort, little or no new evidence is likely, appellate review of novel legal issues has been completed, and a full cycle of trial strategies has been explored.

Id. (footnote omitted). Such criteria generally will not be satisfied in an MDL proceeding.

22. See 28 U.S.C. § 1407(a) (2012).

23. Gelboim v. Bank of Am. Corp., 135 S. Ct. 897, 904-05 (2015) (alteration in original) (quoting § 1407).

24. As the Supreme Court has observed, the drafters of Section 1407 hoped to realize a number of efficiencies, including to "eliminate duplication in discovery, avoid conflicting rulings and schedules, reduce litigation cost, and save the time and effort of the parties, the attorneys, the witnesses, and the courts." Id. at 903 (quoting MANUAL FOR COMPLEX LiTIGATION, supra note 21, § 20.131). See also DUKe L. CTR. FOR JUD. StUd., supra note 1, at 7 (recommending that "[t]he transferee judge should give priority to deciding issues broadly applicable to multiple claimants in the MDL”). 
an MDL proceeding may lead to the filing of less meritorious claims as cases are aggregated, the Panel itself has noted that one of the missions of an MDL judge is to aggressively weed out such "spurious claims." Thus, in In re Seroquel Products Liability Litigation, the Panel noted that "[t]he response to such concerns more properly inheres in assigning all related actions to one judge committed to disposing of spurious claims quickly." 25 As the Panel explained in another transfer order:

[T] he transferee court handling several cases in an MDL likely is in a better position - and certainly is in no worse position than courts in multiple districts handling individual cases - to properly address meritless claims. There are many tools a transferee court may use to accomplish this task. And importantly, if defendants believe plaintiffs' counsel are filing frivolous claims, it is incumbent upon defense counsel to bring that concern to the attention of the transferee court, and to propose a process to identify and resolve such claims. ${ }^{26}$

In other words, the Panel has expressed the view that centralization through MDL consolidation may actually function better in weeding out weak and frivolous claims than allowing cases to proceed in a more dispersed fashion in multiple different fora. Moreover, the Panel has encouraged courts and defendants to adopt procedures to accomplish such ends to ensure that only meritorious claims remain and centralization does not lead to a proliferation of claims of dubious merit.

There are a number of different types of issues that may arise in the sort of large complex litigations that are typically consolidated in MDL proceedings. The Manual for Complex Litigation counsels that "[i]dentifying [such] issues - and the governing statutory or decisional law - is critical to developing a plan for efficiently resolving complex tort litigation." 27 Accordingly, "[i]n early Federal Rule of Civil Procedure 16 conferences and status conferences, the judge and counsel should work to narrow the issues, claims, and defenses." 28 Among the issues the Manual for Complex Litigation gives as examples of "[i]ssues to be taken up early in the litigation" are "whether the facts and expert evidence support a finding that the products or acts in question have the capacity to cause the type of injuries alleged" and "whether one or more classes should be certified." 29

25. In re Seroquel Prods. Liab. Litig., 447 F. Supp. 2d 1376, 1379 (J.P.M.L. 2006).

26. In re Cook Med., Inc., IVC Filters Mktg., Sales Practices and Prods. Liab. Litig., 53 F. Supp. 3d 1379, 1381 (J.P.M.L. 2014) (Mem.).

27. MANUAL FOR COMPLEX LiTigation, supra note $21, \S 22.634$.

28. Id. at 411

29. Id. 
In a product liability action, for example, causation is a critical threshold issue with respect to each claim. Absent credible proof of causation, plaintiffs have no claim against defendants. ${ }^{30}$ Moreover, the evidence supporting such claims must be reliable under Federal Rule of Evidence $702 .{ }^{31}$ In order to obtain a jury verdict in their favor, plaintiffs must have admissible expert testimony demonstrating causation. ${ }^{32}$ Accordingly, as discussed more fully below, substantive rulings regarding causation as well as rulings on the admissibility of expert evidence relating to causation under Federal Rule of Evidence 702 and Daubert v. Merrell Dow Pharmaceuticals ${ }^{33}$ have often been dispositive in large MDL proceedings involving product liability claims.

Similarly, product identification is often an important threshold issue. ${ }^{34}$ Plaintiffs must demonstrate that it was the defendant's product, and not some other manufacturer's, that caused their alleged injury.

30. See, e.g., Hisrich v. Volvo Cars of N. Am., Inc., 226 F.3d 445, 450 (6th Cir. 2000); Soldo v. Sandoz Pharms. Corp., 244 F. Supp. 2d 434, 524 (W.D. Pa. 2003) ("Proof of causation is a necessary element in a products liability action. Absent a causal relationship between the defendant's product and the plaintiff's injury the defendant cannot be held liable on a theory of negligence, strict product liability, or misrepresentation."); In re Meridia Prods. Liab. Litig., 328 F. Supp. 2d 791, 798 (N.D. Ohio 2004) ("First, a plaintiff must show that the substance to which she was exposed can cause the type of injury alleged."); RESTATEMENT (THIRD) OF TORTS: LIAB. PHYSICAL HARM § 28(a), § $28 \mathrm{cmt}$. (c)(1) (AM. LAW INST. 2010).

31. See Fed. R. Evid. 702; Daubert v. Merrell Dow Pharms., Inc., 509 U.S. 579, 589 (1993); see also generally MANUAL FOR COMPLEX LITIGATION, supra note 21, §§ 23.1-23.37.

32. See, e.g., Daubert, 509 U.S. at 589 (evidence in prescription drug case must be admissible expert testimony that is both relevant and reliable); Amorgianos v. Nat'l R.R. Passenger Corp., 303 F.3d 256, 268 (2d Cir. 2002) ("[T] establish causation, [plaintiffs] must offer admissible expert testimony regarding both general causation, i.e., that xylene exposure can cause the type of ailments from which [plaintiffs claim] to suffer; and specific causation, i.e., that xylene exposure actually caused [their] alleged neurological problems.”); Pride v. BIC Corp., 218 F.3d 566, 580 (6th Cir. 2000) ("Without admissible expert testimony on causation and product defect, no reasonable jury could find for [plaintiff] . . . ."); Sandoz Pharms., 244 F. Supp. 2d at 525 (observing that in prescription drug case "involving complex issues of causation not readily apparent to the finder of fact, plaintiff must present admissible expert testimony to carry her burden"); Bouchard v. American Home Prods. Corp., 213 F. Supp. 2d 802, 806 (N.D. Ohio 2002) (“A jury should not be allowed to speculate as to causation, and to eliminate that speculation an expert witness may be necessary.").

33. See generally 509 U.S. 579 (1993).

34. See, e.g., Garcia v. Pfizer, Inc., 268 F. App’x 270, 273 (5th Cir. 2008) (“[I]t was not sufficient for Garcia to introduce evidence that the Defendants distributed OPV in Texas in 1970. Instead, she must have adduced evidence that Defendants supplied the specific doses that allegedly caused her injury.”); Bruesewitz v. Wyeth, Inc., 508 F. Supp. 2d 430, 448 (E.D. Pa. 2007) (dismissing failure to warn claims because "Plaintiffs ... produced no evidence from which a trier of fact could infer that the dose in question originated in a lot of vaccine associated with a disproportionate number of adverse health effects"); Hanks by Old Nat'l Trust Co. v. Korea Iron \& Steel Co., 993 F. Supp. 1204, 1212 (S.D. Ill. 1998) (granting summary judgment when plaintiff "can show, at best, only that Kiswire [source of wire rope] was a 'possible' but not a 'probable' manufacturer of the wire rope that failed" because the wire rope could have come from "numerous other sources"); In re Dow Corning Corp., 250 B.R. 298, 353-54 (Bankr. E.D. Mich. 2000) ("It is well established that product identification is an essential element of every products liability action, regardless of which state's law governs."). 
Product identification is therefore a critical piece in the causal chain establishing liability.

Whether plaintiffs' claims are barred because adequate warnings accompanied the defendant's product is another potential threshold issue. ${ }^{35}$ Plaintiffs cannot pursue claims based on the alleged hazards of a product where the court determines that the warnings accompanying the product were adequate or that plaintiffs in fact had sufficient information to put them on notice of the alleged hazards.

The statute of limitations can also be an important threshold issue that will resolve the litigation or narrow it to claims based on certain time periods. Where plaintiffs were on notice of their claims due to publicity regarding the alleged injuries outside the statutory limitations period, their claims are barred as a matter of law and they cannot pursue them. ${ }^{36}$ Accordingly, rulings on statute of limitations can be used to significantly narrow the litigation or eliminate it entirely.

Finally, as discussed more fully below, in recent years, defendants have increasingly raised federal preemption as a bar to product liability claims in MDL proceedings. State law product liability claims that are contrary to federal law are barred under the Supremacy Clause, and courts have applied this principle to dismiss pharmaceutical claims asserting that warnings were inadequate where there is evidence that the FDA would not have approved stronger warnings. ${ }^{37}$ Likewise, generic pharmaceutical manufacturers have repeatedly invoked the doctrine to bar claims that they should have included additional or different warnings to their labeling on the ground that they are not permitted under federal law to adopt warnings that are different than those used with the matching branded pharmaceutical product. ${ }^{38}$

35. See, e.g., In re Meridia, 328 F. Supp. 2d at 811; In re Norplant Contraceptive Prods. Liab. Litig., 215 F. Supp. 2d 795, 806-09 (E.D. Tex. 2002) (cataloguing cases in forty-eight jurisdictions adopting learned intermediary doctrine).

36. See, e.g., Ball v. Union Carbide Corp., 385 F.3d 713, 722-23 (6th Cir. 2004) (claims alleging exposure to radiation emitted by nuclear weapons plant were time barred as a result of widespread publicity); Blanton v. Cooper Indus., Inc., 99 F. Supp. 2d 797, 799, 802-03 (E.D. Ky. 2000) (claims alleging environmental contamination from National Electric Coil plant were time barred due to "widespread reports by local, regional and national media"); In re Burbank Environ. Litig., 42 F. Supp. 2d 976, 981 (C.D. Cal. 1998) (plaintiffs on notice of claims where "[a] plethora of newspaper articles and multiple newscasts prior to 1993 reported Lockheed's involvement in contamination of the Burbank area"); Carey v. Kerr-McGee Chem. Corp., 999 F. Supp. 1109, 1111, 1115-16 (N.D. Ill. 1998) ("extensive, widespread publicity" barred claims by property owners alleging property damage from disposal of radioactive material: "The discovery rule does not allow a plaintiff to wait until the defendant admits it has caused plaintiff's damage. That would be a very long wait indeed. The rule places the burden on plaintiffs to inquire as to the existence of a cause of action.").

37. See, e.g., In re Fosamax (Alendronate Sodium) Prods. Liab. Litig. (No. II), 751 F.3d 150, 155 (3d Cir. 2014).

38. See id. 
The standard way in which such issues are resolved is at the outset of the litigation through omnibus motions to dismiss or for summary judgment on all, or specific categories of, claims. ${ }^{39}$ Summary judgment motions may be coupled with motions to exclude particular evidence, such as motions to exclude expert evidence as unreliable under Rule 702 and Daubert. Nonetheless, issues that may be dispositive of larger categories of claims are sometimes also raised through case-specific motions. Once a litigant obtains a ruling in one of the cases pending before the MDL court, it may be merely an administrative matter to apply that ruling to other similar cases that are pending before the same court.

In addition to formal motion practice, active case management also may be utilized to narrow the issues in an MDL proceeding. Rule 16 encourages the Court to exercise its case management authority to "formulat[e] and simplify[] the issues, and eliminat[e] frivolous claims or defenses." 40 This includes "limiting the use of testimony under Federal Rule of Evidence 702,"41 and "controlling and scheduling discovery, including orders affecting disclosures and discovery under Rule 26 and Rules 29 through 37." 42 The various provisions in the Rule were designed to "encourage[] the court to become involved in case management early in the litigation" and "to stimulate litigants to narrow the areas of inquiry and advocacy to those they believe are truly relevant and material." 43 The drafters hoped to "promot[e] efficiency and conserv[e] judicial resources by identifying the real issues prior to trial, thereby saving time and expense for everyone." 44 Indeed, the Rule contemplates that such narrowing of the issues need not "await a formal motion for summary judgment" and may be accomplished by stipulation. ${ }^{45}$ Accordingly, standard proceedings under the Federal Rules may be utilized in an MDL proceeding to obtain rulings on common issues that may significantly narrow, or resolve entirely, large categories of claims.

39. The Federal Judicial Center's guide for MDL proceedings specifies a "summary judgment motions deadline" as one of the key deadlines typically contained in an MDL case management order. Barbara J. Rothstein \& Catherine R. Borden, Fed. Jud. Ctr., Managing Multidistrict Litigation IN PRODUCtS Liability CASES: A POCKET GUIDE FOR TRANSFEREE JUdGES 17 (2011) [hereinafter ROTHSTEIN \& BORDEN, POCKET GUIDE], https://www.fjc.gov/sites/default/files/ 2012/MDLGdePL.pdf.

40. FED. R. CIV. P. 16(c)(2)(A).

41. FED. R. CIV. P. 16(c)(2)(D).

42. FED. R. CIV. P. 16(c)(2)(F).

43. FED. R. CIV. P. 16(b) advisory committee's note to 1983 amendment.

44. FED. R. CIV. P. 16(c) advisory committee's note to 1983 amendment.

45. Id.; see also Gen. Elec. Co. v. Joiner, 522 U.S. 136, 149 (1997) (Breyer, J., concurring) (noting that among the federal judiciary there is "an increased use of Rule 16's pretrial conference authority to narrow the scientific issues in dispute"). 
This may take the form of omnibus motions that relate to all claims in the MDL proceeding or to certain categories of claims. It may take the form of individual motions for summary judgment that are relevant to an individual case, or which may tee up critical issues that have broader applicability. In the latter situation, once an issue has been litigated in one case, it may be a fairly straightforward matter to apply that ruling in subsequent cases.

In addition to these formal proceedings, the scope of litigation may be narrowed in less formal ways. For example, as discovery proceeds and defendants collect information on individual claims, a process may be initiated by which defendants approach plaintiffs' counsel and identify those cases that they believe are fundamentally flawed and should be voluntarily dismissed without involving the court through formal motion practice. It may be that defendants discover that there are problems with product identification, issues regarding individual medical causation evidenced by the plaintiff's medical records, or other reasons demonstrating that the claims are not viable. MDL courts routinely order the disclosure of information in plaintiff fact sheets along with production of key documents (for example, production of medical records in cases involving allegations of personal injury). ${ }^{46}$ Defendants can ascertain from these materials and more formal discovery whether there are problems with particular individual cases that have been filed and raise them with plaintiffs' counsel. If the parties are unable to reach an agreement, such issues may then be raised with the court in individual cases on a rolling basis. In this manner, the scope of the claims truly at issue can be narrowed without undue expenditure.

Some courts have found it useful to employ additional procedures to accomplish similar results in slightly more formal ways. For example, courts have issued Lone Pine ${ }^{47}$ orders requiring each plaintiff to provide basic information along with an affidavit from a medical expert to support the plaintiff's claim. ${ }^{48}$ Depending on the circumstances, such more formal

46. See DuKE L. CTR. FOR Jud. Stud., supra note 1, at 14-15 ("One of the most useful and efficient initial mechanisms for obtaining individual plaintiff discovery is the use of fact sheets. . . Similarly, requiring the collection of plaintiffs' medical records (in personal injury cases) or employment histories (in employment cases) is another straightforward way that MDL courts can encourage a robust exchange of key information at a relatively early stage."); U.S. CHAMBER, supra note 1 , at 17 .

47. Lore v. Lone Pine Corp., No. L 33606-85, 1986 N.J. Super. LEXIS 1626 (N.J. Super. Ct. Law Div. Nov. 18, 1986).

48. U.S. CHAMBER, supra note 1, at 17-19; see also, e.g., In re Zimmer NexGen Knee Implant Prods. Liab. Litig., No. 1:11-cv-05468, 2016 WL 3281032, at*2 (N.D. Ill. June 10, 2016); In re Fosamax Prods. Liab. Litig., No. 06 MD 1789(JFK), 2012 WL 5877418, at *2 (S.D.N.Y. Nov. 20 2012) (Lone Pine order being used with "increasing frequency" in MDLs to "streamline the docket"); 
procedures may be appropriate to weed out claims that on their face are simply not viable, allowing the court to focus on the claims that are truly at issue in the litigation.

This parallel track that gives scrutiny to individualized cases can be critical because some issues that are dispositive of cases will inherently be more individualized. Thus, while common issues may dispose of all, or large categories of claims, there may be additional claims that can be quickly and efficiently resolved through such individualized scrutiny in the MDL proceedings. Moreover, such scrutiny will ameliorate some of the concerns that critics of MDL proceedings have expressed-i.e., that aggregating claims in an MDL proceeding allows plaintiffs' counsel to shield frivolous claims from scrutiny by lumping them in with other claims and avoiding individualized treatment. ${ }^{49}$ As one MDL judge has observed, "[r] egardless of the amount of judicial effort and resources, unless the court establishes a toll gate at which entrance to the litigation is controlled, non-meritorious cases will clog the process." ${ }^{50}$ Indeed, some commentators have gone so far as to argue that because of such concerns, the "MDL, as currently structured, must be deemed unconstitutional, because it infringes on individual claimants' procedural due process rights." ${ }^{, 51}$ This separate, more individualized review, should mitigate such concerns. $^{52}$

In re Vioxx Prods. Liab. Litig., 557 F. Supp. 2d 741, 744-45 (E.D. La. 2008); In re Rezulin Prods. Liab. Litig., No. 00 Civ. 2843(LAK), 2005 WL 1105067, at *1 (S.D.N.Y. May 9, 2005); DUKE L. CTR. FOR JUD. STUD., supra note 1, at 15-16.

49. As the Mentor court observed:

$[T]$ he evolution of the MDL process toward providing an alternative dispute resolution forum for global settlements has produced incentives for the filing of cases that otherwise would not be filed if they had to stand on their own merit as a stand-alone action. Some lawyers seem to think that their cases will be swept into the MDL where a global settlement will be reached, allowing them to obtain a recovery without the individual merit of their cases being scrutinized as closely as it would if it proceeded as a separate individual action.

In re Mentor Corp. Obtape Transobturator Sling Prod. Liab. Litig., No. 4:08-MD 2004 (CDL), 2016 WL 4705827, at*1-2 (M.D. Ga. Sept. 7, 2016) (Mem.).

50. Hon. Eduardo C. Robreno, The Federal Asbestos Product Liability Multidistrict Litigation (MDL-875): Black Hole or New Paradigm?, 23 WidENER L.J. 97, 186 (2013). As Judge Robreno further observed, one mechanism for achieving this goal is to require early fact disclosure by plaintiffs accompanied by dismissal for noncompliance: "[C]ourts must establish procedures by which, at an early point, each plaintiff is required to provide facts which support the claim through expert diagnostics reports or risk dismissal of the case." Id. at 187.

51. Martin H. Redish \& Julie M. Karaba, One Size Doesn't Fit All: Multidistrict Litigation, Due Process, and the Dangers of Procedural Collectivism, 95 B.U. L. REv. 109, 151 (2015). See also Robreno, supra note 50, at 187 ("Aside from the significant due process issues raised by forcing parties to litigate or settle cases in groups, aggregation promotes the filing of cases of uncertain merit. The incentive becomes the number of cases that can be filed, not the relative merit of the individual case.").

52. Early production of information and scrutiny of individualized claims may also facilitate settlement discussions. One group of experts has observed that "settlement talks are often delayed precisely because the parties have not anticipated the need for assembling information necessary to 


\section{RESOLUTION OF COMMON ISSUES}

The framework established by federal statute and case law developed over the last several decades has been applied effectively to resolve largescale, dispersed litigation involving common questions of fact and law. The resolution of such common issues has arisen in a variety of kinds of cases, including pharmaceutical, medical device and other product liability actions, antitrust, employment, and other cases subject to consolidation in MDL proceedings. ${ }^{53}$

\section{A. Causation Issues}

As noted above, one of the primary common issues that has been litigated in product liability cases such as those involving pharmaceuticals and medical devices is the issue of causation. ${ }^{54}$ Numerous courts have utilized rulings on omnibus motions for summary judgment along with corresponding Daubert proceedings in order to narrow or even resolve entirely complex multidistrict litigation. The Federal Judicial Center has encouraged MDL judges that they "should encourage the resolution of scientific disputes" regarding causation and other matters: "Judges must grapple with scientific issues in their roles as gatekeepers." 55

\section{The PPA MDL}

In the phenylpropanolamine (PPA) litigation, for example, resolution of Daubert motions played a significant role in determining which claims should receive compensation. ${ }^{56}$ After discovery and hearings regarding

assess the strengths and weaknesses of the global litigation and examine the potential value of individual claims." DUKE L. CTR. FOR JUD. STUD., supra note 1, at 14.

53. See, e.g., Meridia Prods. Liab. Litig. v. Abbott Labs., 447 F.3d 861 (6th Cir. 2006); In re Mirena IUD Prods. Liab. Litig., 202 F. Supp. 3d 304 (S.D.N.Y. 2016); In re Indep. Serv. Orgs. Antitrust Litig., 964 F. Supp. 1479 (D. Kan. 1997).

54. See RothSTEIN \& BORDEN, POCKET GUIDE, supra note 39, at 35 ("Because expert opinions play a vital role in many products liability MDLs, both during the discovery process and at trial, you should establish at any early pretrial conference a schedule for disclosing expert opinions in written reports, for deposing the experts, and for resolving Daubert motions.").

55. Id. at 36 .

56. See generally Hon. Barbara J. Rothstein et al., A Model Mass Tort: The PPA Experience, 54 DRAKE L. REV. 621 (2006). As the trial judge presiding over the PPA litigation later wrote:

The In re PPA court's decision to take an aggressive role in determining the admissibility of scientific evidence had the important practical result of setting clear parameters for motions for summary judgment. Where the plaintiffs' experts' testimony is ruled inadmissible, the plaintiffs' cases are usually subject to dismissal. Once the Daubert issues were decided, the court could rule on motions for summary judgment. Such motions are a major vehicle for reducing meritless claims in a large litigation. 
the scientific evidence of causation, the district court presiding over the MDL proceedings issued a ruling that granted in part defendants' Daubert motion. ${ }^{57}$ The court excluded evidence regarding a causative link between PPA and hemorrhagic or ischemic stroke where plaintiffs had not taken the medication within seventy-two hours of their stroke and further excluded expert evidence regarding any causal link between PPA and all other alleged injuries such as seizures, cardiac injuries, and psychoses. ${ }^{58}$ Not only did the district court's ruling have a significant effect on the federal litigation because it was often outcome-determinative with respect to subsequent motions for summary judgment, but it also influenced state court litigation, particularly given that the federal court had invited state court judges presiding over similar litigation to attend the Daubert hearings. ${ }^{59}$

As Judge Rothstein, the trial judge presiding over the $P P A$ litigation and the subsequent Director of the Federal Judicial Center, later wrote: "The approach employed in In re PPA has become accepted as a model case management technique for incorporating the trends toward global resolution of scientific issues while respecting the limitations placed on the transferee judge by the Lexecon decision." ${ }^{60}$ The court's Daubert rulings "had the important practical result of setting clear parameters for motions for summary judgment," which Judge Rothstein observed are "a major vehicle for reducing meritless claims in a large litigation." 61

\section{The Heparin MDL}

The Heparin MDL litigation provides another example in which MDL consolidation of cases followed by motion practice on generic issues proved successful in ultimately resolving the litigation. Heparin is an anticoagulant used in dialysis procedures as well as various cardiac procedures such as cardiac bypass surgery. ${ }^{62}$ The Heparin litigation stemmed from a widely-publicized instance of contamination of heparin manufactured in China, which resulted in hundreds of complaints of adverse events and a significant investigation by both the FDA and CDC. ${ }^{63}$

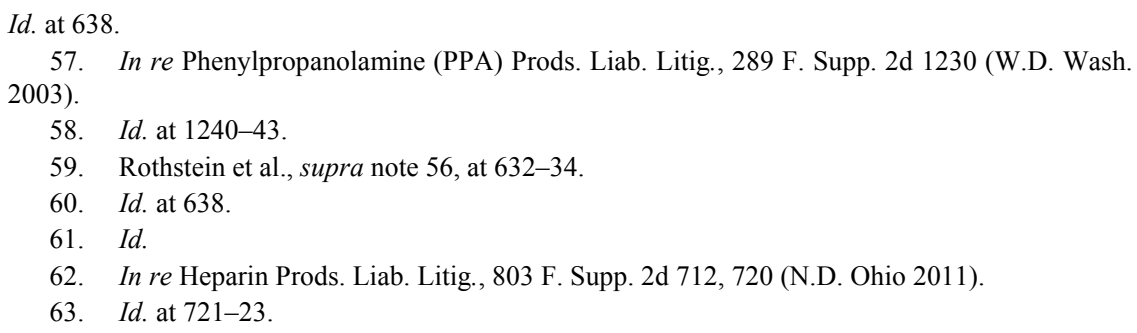


As in other pharmaceutical litigation, the heparin claims arose within a patient population that suffered from serious pre-existing medical conditions. $^{64}$

Adverse events of the sort alleged in the heparin litigation were quite common in the population receiving heparin therapy. For example, patients with end stage renal disease, who would be receiving heparin through dialysis treatment suffered a significant background mortality rate. ${ }^{65}$ Further, studies had shown that "cardiac disease is the major cause of death in dialysis patients, accounting for approximately $45 \%$ of allcause mortality." ${ }^{\prime 66}$ As the CDC observed in its study of the adverse reactions, such reactions were not uncommon, and "[s]imilar adverse reactions" had arisen due to a variety of different causes:

Similar adverse reactions have been documented among patients undergoing dialysis and have, in the past, been attributed to many causes, including dialyzer membranes, water impurities, residual disinfectants, and medications such as ACE inhibitors. A systemic inflammatory response has also been described in the setting of cardiopulmonary bypass and has been attributed to activation of the contact system resulting from interactions of blood with the artificial surfaces of the bypass circuit and other mechanisms that activate the kinin-kallikrein pathway, complement system, and other systems. ${ }^{67}$

The situation with patients receiving heparin in cardiac artery bypass procedures was similar, with patients experiencing such adverse cardiovascular events due to multiple potential causes having nothing to do with contamination. ${ }^{68}$

Accordingly, regulatory authorities noted at the time that the sorts of events reported in patients receiving contaminated heparin occurred commonly in the absence of any contamination. The FDA noted, for

64. Id. at 720 ("Many patients who receive heparin have serious pre-existing medical conditions. Patients with end-stage renal disease and patients undergoing coronary artery bypass surgery make up a significant number of those receiving vial heparin.").

65. See David B. Blossom et al., Outbreak of Adverse Reactions Associated with Contaminated Heparin, 359 N. ENG. J. MED. 2674, 2682 (Dec. 3, 2008), http://www.nejm.org/doi/pdf/ 10.1056/NEJMoa0806450.

66. Charles A. Herzog, Cardiac Arrest in Dialysis Patients: Approaches to Alter an Abysmal Outcome, 63 KIDNEY INT'L S84, S197 (2003), http://www.kidneyinternational-online.com/article/ S0085-2538(15)49250-6/pdf.

67. Blossom et al., supra note 65, at 2682 (“describ [ing] a CDC epidemiologic investigation ... [and] provid[ing] a clinical description of the reactions that occurred after the administration of heparin").

68. Norman J. Snow et al., Cardiothoracic Surgery: Diseases of the Heart, Great Vessels, and Thoracic Cavity, in EsSEnTIALS OF SURGiCAL SPECIALTIES 261 (P. Lawrence et al. eds., 2nd ed. 2000) ("Essentially all organ systems can be affected by complications of CABG and the physiologic disruptions associated with the heart lung machine.”). 
example, that "[j] ust because there's a report in a patient that took Heparin doesn't necessarily mean that Heparin caused the event. . . . [T]here are all kinds of events that occur. A lot of these patients are very, very sick." 69 The heparin litigation thus mimicked other pharmaceutical litigations in which plaintiffs' counsel have sought out incidents of alleged injury occurring in a population with a significant background rate in an attempt to attribute some portion of that background rate to exposure to a pharmaceutical product.

After reviewing the parties' briefing and receiving expert testimony presented at a Daubert hearing, the court entered an order that had the effect of significantly narrowing the litigation. The court ruled that several large categories of claims lacked reliable scientific support. ${ }^{70}$ The court's ruling was firmly rooted in the scientific evidence regarding causation. The CDC had performed a study examining events that occurred after receiving contaminated heparin using a case definition for anaphylactoid events that occurred within sixty minutes of administration. ${ }^{71}$ As the court observed, there was no epidemiological evidence supporting adverse events that occurred outside this case definition. ${ }^{72}$ Instead, plaintiffs relied upon a variety of theoretical constructions based on animal and in vitro studies and hypothesized mechanisms of action. ${ }^{73}$ The court concluded that there was simply too great a gap in the available data and the expert's opinions. $^{74}$

The court also concluded that there was no reliable evidence that contaminated heparin given in certain particular routes of administration could cause adverse health effects. ${ }^{75}$ Specifically, the court determined that there was no reliable evidence that contaminated heparin absorbed

69. Transcript of Press Conference, FDA (Feb. 28, 2008), https://www.fda.gov/downloads/ NewsEvents/Newsroom/MediaTranscripts/UCM169342.pdf [https://wayback.archive-it.org/7993/ 20170406155231/]; See also Information on Adverse Event Reports and Heparin, FDA., https://www.fda.gov/Drugs/DrugSafety/PostmarketDrugSafetyInformationforPatientsandProviders/u cm112597.htm (last visited Dec. 12, 2017) ("The fact that allergic symptoms or hypotension was reported does not mean that these were the cause of death in all cases... . Reports have to be analyzed to see if there is a plausible causal association between the drug and the medical event. . . Many patients have other serious conditions that could have caused the reported problem."); Transcript of Press Conference, FDA (April 21, 2008), https://www.fda.gov/downloads/NewsEvents/Newsroom/ MediaTranscripts/UCM169333.pdf [https://wayback.archive-it.org/7993/20170406155133/] ("[A]s we have repeatedly pointed out, just because somebody got heparin and they had a reaction, it doesn't imply a causal relationship and there's always been some background incidents in these reactions reported.").

70. In re Heparin Prods. Liab. Litig, 803 F. Supp. 2d 712, 753-54 (N.D. Ohio 2011).

71. Id. at 721

72. Id. at 739,753 .

73. See id. at 739 (concluding that such expert opinion was merely "speculative").

74. Id. at 753 (quoting Gen. Elec. Co. v. Joiner, 522 U.S. 136, 146 (1997)).

75. Id. at $753-54$. 
through subcutaneous administration, as opposed to intravenous administration, could cause adverse health effects. ${ }^{76}$ In support of her opinions on this issue, plaintiffs' expert cited an abstract she had coauthored describing a study in rats, which showed that contamination was absorbed after subcutaneous administration. However, as the court noted, the study did not support the expert's conclusions:

[The expert] does not explain, nor does the abstract elucidate how human effects could be extrapolated from these results in rats. Nor does she explain how she arrived at her opinion that the study confirms that subcutaneous administration of contaminated heparin can cause harm in patients (a conclusion not part of the published abstract). ${ }^{7}$

Accordingly, the court again concluded that there was "too great an analytical gap" between the expert's opinions and the data on which they were based. $^{78}$

Finally, the court excluded expert opinions asserting that contaminated heparin could "cause a sepsis-like response or aggravate sepsis or disseminated intravascular coagulation (DIC)." 79 The court noted that "[t]here has been no study that has looked at OSCS contaminated heparin and its effects in septic patients." ${ }^{80}$ While plaintiffs" expert had cited literature on "feedback loops" and the claim that OSCS activated the complement system, the court concluded that the expert "presents nothing that would link the feedback loop responses she theorizes based on the literature to patients exposed to contaminated heparin." 81 The court therefore concluded that "there is "simply too great an analytical gap between the data and the opinion proffered.", 82

Based on these Daubert rulings, the court granted summary judgment on these categories of claims, which represented more than fifty percent of the claims asserted in the litigation. Accordingly, like the $P P A$ litigation, the court's rulings on these common issues significantly advanced the resolution of the overall litigation by disposing of large categories of asserted claims.

\footnotetext{
76. Id. at $739-40$.

77. Id.

78. Id. at 753 .

79. Id. at 738 .

80. Id.

81. Id. ("[The expert] has done no experiments demonstrating the ability of OSCS or OSCS contaminated heparin to cause such feedback loops, nor can she point to studies published by others.").

82. Id. (quoting Gen. Elec. Co. v. Joiner, 522 U.S. 136, 146 (1997)). The court also ruled that claims alleging "clotting effects" apart from HIT were inadmissible under Rule 702 and Daubert, noting that plaintiffs had failed to make "any showing that any such opinion offered . . . is based on reliable methodology." Id. at 736.
} 
3. The Lipitor MDL

The Lipitor MDL addressed claims that a statin medication used to treat high cholesterol increased patients' risk of developing Type 2 diabetes. As with many pharmaceutical claims, there was a significant background rate of diabetes in the population that was prescribed this cholesterol-reducing medication. The court considered dispositive omnibus motions for summary judgment and to exclude plaintiffs' expert evidence under Rule 702 and Daubert, issuing rulings that were largely dispositive of the litigation.

The studies that had examined the question of whether Lipitor was associated with an increased risk of Type 2 diabetes examined the effects at various dosages, ranging from $10 \mathrm{mg}$ to $80 \mathrm{mg} .{ }^{83}$ While the studies generally found no association with the lower dosages, there was a statistically significant increased risk observed in the $80 \mathrm{mg}$ dosage. ${ }^{84}$

In considering this scientific evidence, the court excluded expert testimony regarding general causation at doses below $80 \mathrm{mg} .{ }^{85}$ The court reasoned that, because epidemiological studies on the lower doses had found no statistically significant increased risk, expert opinions that general causation was established at these lower doses were "not based on sufficient facts and data." ${ }^{\circ 6}$ Similarly, the court concluded that in offering opinions regarding general causation, plaintiffs' expert "did not reliably apply the epidemiological/Bradford Hill method because this method requires a statistically significant association be established through studies and such studies do not exist." ${ }^{87}$ The court rejected plaintiffs' efforts to substitute alleged "admissions" regarding causation found in company documents, such as internal emails or labeling in foreign countries, for actual scientific data establishing a statistically significant increased risk. ${ }^{88}$

The court declined to grant the motion with respect to the $80 \mathrm{mg}$ dose because there was epidemiological evidence indicating that patients taking

83. See In re Lipitor (Atorvastatin Calcium) Mktg., Sales Practices and Prods. Liab. Litig., 227 F. Supp. 3d 452, 462 (D.S.C. 2017), appeal docketed sub. nom. Plaintiffs Appealing CMO 109 v. Pfizer, Inc., No. 17-1136 (4th Cir. Mar. 2, 2017).

84. Id. at $462-63$.

85. Id. at 457. The four doses that were raised were $10 \mathrm{mg}, 20 \mathrm{mg}, 40 \mathrm{mg}$ and $80 \mathrm{mg}$. Id. at 462.

86. Id. at 463 .

87. Id. The court also excluded the opinion of an endocrinologist who opined on general causation, who the court concluded "cherry-picked studies to support his conclusion rather than considering the totality of the literature." Id.

88. Id. at 478-86 ("Here, expert testimony is certainly required."). 
Lipitor had a relative risk ratio of developing diabetes greater than 2.0. ${ }^{89}$ However, this ruling did not have much practical effect because plaintiffs' counsel in the MDL were unable to identify any actual plaintiffs who had taken this higher dose. Despite repeated opportunities from the court, plaintiffs' counsel did not come forward with evidence that any of the plaintiffs had taken the $80 \mathrm{mg}$ dose. ${ }^{90}$

The court also excluded certain specific causation opinions of experts proffered for the bellwether cases on the ground that "their opinions were based on nothing more than an increased risk and temporal association." 91 The court noted the difficulty of establishing specific causation "where the alleged injury is a complicated, progressive, multi-factor disease like diabetes." 92 In particular, the court cited two decisions - the Eleventh Circuit's decision in Guinn v. AstraZeneca Pharmaceuticals $L P^{93}$ and the Florida District Court's decision in Haller v. AstraZeneca Pharmaceuticals $L P^{94}$-as relevant precedent. In Guinn, the Eleventh Circuit held that similar opinions alleging that the pharmaceutical Seroquel caused diabetes were unreliable and therefore inadmissible under Rule 702. ${ }^{95}$ The expert in Guinn was unable to reliably rule out other causes of the plaintiff's diabetes, and the court rejected the contention that the expert could simply assert that all risk factors, including Seroquel, worked together to cause diabetes. ${ }^{96}$ In Haller, the court rejected opinions that Seroquel caused diabetes for similar reasons. There, too, plaintiff's expert was unable to rule out other potential causes of diabetes. The court observed that a mere temporal connection between taking a pharmaceutical and the development of disease was not a reliable basis to establish specific causation under Rule 702 and Daubert. ${ }^{97}$

The court in Lipitor followed these cases and found that the opinions offered by plaintiffs' specific causation experts were flawed for similar reasons. ${ }^{98}$ As the court observed, there were many other potential causes of diabetes, including the plaintiff's BMI, adult weight gain, family

\footnotetext{
89. Id. at 457

90. See id. at $457-62$.

91. Id. at 457 .

92. Id. at 464 .

93. Guinn v. AstraZeneca Pharm. LP, 602 F.3d 1245 (11th Cir. 2010).

94. Haller v. AstraZeneca Pharm. LP, 598 F. Supp. 2d 1271 (M.D. Fla. 2009).

95. Guinn, 602 F.3d at 1254.

96. Id. at 1255 ("An expert ... cannot merely conclude that all risk factors for a disease are substantial contributing factors in its development.").

97. Haller, 598 F. Supp. 2d at 1297-98.

98. In re Lipitor (Atorvastatin Calcium) Mktg., Sales Practices and Prods. Liab. Litig., $227 \mathrm{~F}$. Supp. 3d 452, 464 (D.S.C. 2017), appeal docketed sub. nom. Plaintiffs Appealing CMO 109 v. Pfizer, Inc., No. 17-1136 (4th Cir. Mar. 2, 2017).
} 
history, age, and hypertension. The expert never performed any analysis showing why these "other risk factors for diabetes, alone or in combination, were not solely responsible for [plaintiff's] diabetes." 99 Accordingly, the court concluded that the opinions were inadmissible under Rule 702 and Daubert. In granting in part defendant's omnibus motions for summary judgment, the court noted that such procedures were effective in furthering the goals of the MDL process: "Ruling on an omnibus motion for summary judgment that involve [sic] issues common to all cases, such as whether a claim can survive summary judgment without expert testimony on specific causation, 'will promote the just and efficient conduct' of these actions and, thus, is the type of 'coordinated or consolidated pretrial proceedings' envisioned by Section 1407."100

\section{The Mirena MDL}

Courts have also issued rulings under Rule 702 and Daubert to significantly narrow or eliminate claims in medical device litigation. In the Mirena product liability litigation, for example, the court granted defendants' omnibus motion for summary judgment on the issue of causation after issuing rulings excluding plaintiffs' expert evidence as unreliable under Rule 702 and Daubert. ${ }^{101}$

The Mirena litigation involved a plastic intrauterine device that delivered a hormone in order to prevent pregnancy for up to five years. ${ }^{102}$ Plaintiffs alleged that the device was defectively designed and, as a result, perforated, became embedded in, or migrated from plaintiffs' uteruses. ${ }^{103}$ The court excluded all of plaintiffs' experts who offered opinions on general causation, laying the basis for granting summary judgment. ${ }^{104}$

The court provided an extensive analysis as to each expert in excluding the experts' opinions. In barring their testimony, the court noted that the theory regarding the mechanism by which Mirena allegedly caused secondary perforations "ha[d] never been tested or studied in human patients, nor ha[d] it undergone animal or in vitro testing," had not been "subjected to peer review and publication," "ha[d] produced no "known or potential rate of error," and had not "gained 'general acceptance' within the scientific community." 105 The court further

\footnotetext{
99. Id. at 465 .

100. Id. at 490 (citations omitted).

101. In re Mirena IUD Prods. Liab. Litig., 202 F. Supp. 3d 304, 327-28 (S.D.N.Y. 2016).

102. Id. at 306.

103. See id. at 307.

104. In re Mirena IUD Prods. Liab. Litig., 169 F. Supp. 3d 396, 427-88 (S.D.N.Y. 2016).

105. Id. at 429-30 (quoting Daubert v. Merrell Dow Pharms., Inc., 509 U.S. 579, 592-94 (1993)).
} 
observed that the fact that expert testimony, like that presented in the Mirena litigation, was "developed solely for litigation" could "weigh against reliability." 106

The court found that the plaintiffs' expert analysis was results-oriented in the sense that the experts were "given a conclusion by lawyers"-i.e., that Mirena caused secondary perforations - "and worked backwards to hypothesize a mechanism by which it might occur."107 The court concluded that such an approach was unreliable, reasoning: "This exercise does not seem to have involved any scientific methodology, but rather consisted of reverse-engineering a theory to fit the desired outcome. This does not rise to the level of intellectual rigor employed in the medical or scientific field ...."108

Noting that expert analysis must be "reliable at every step," the court went through plaintiffs' hypothesized mechanism, finding that there was a lack of scientific support at each step. ${ }^{109}$ The court observed, for example, that, while plaintiffs hypothesized that the hormone that was released from the IUD had a "foreign body effect" on the myometrium of the uterus (the layer of muscle in the uterus), causing it to become thinner, the studies that plaintiffs cited dealt with the endometrium (a thin layer of glandular tissue in the uterus). ${ }^{110}$ The court similarly rejected the plaintiffs' attempt to extrapolate effects on one type of layer to another, noting: "This type of speculation, whereby the conclusions are linked to studies only by [the expert's] say-so, is impermissible under Daubert."111

The court likewise found unreliable expert opinion regarding the next step of the proposed mechanism, which hypothesized that uterine cells grew around the IUD to "attach it to the uterine wall." "112 Again, there was no scientific study supporting this step of the analysis: plaintiffs' expert had "disavowed the one article he cited to support this claim." 113 The court rejected the claim that a hormone released in the uterus weakened uterine tissue. ${ }^{114}$ Examining the studies that plaintiffs cited, the court found that

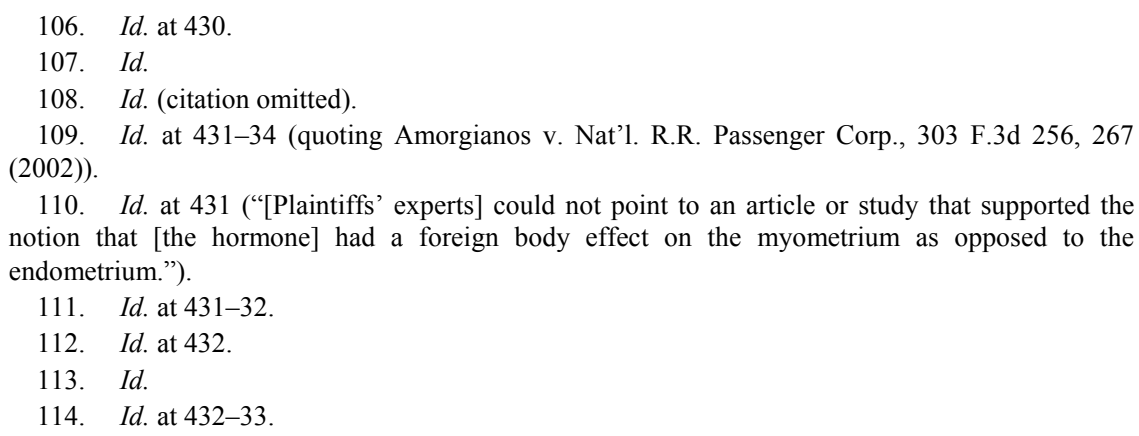


they "seemingly contradict[ed]" this proposition. ${ }^{115}$ While plaintiffs' experts relied on the fact that the studies found that another contraceptive that contained progestin (Depo-Provera) had a weakening effect on uterine tissue, the study authors did not attribute this weakening effect to progestin and in fact found that "another progestin-containing contraceptive ... had no such effect."116 The court determined therefore that the expert's reasoning from this study data was unreliable:

To conclude that Mirena would cause the same effect as Depo-Provera because they both contain progestin-particularly when other contraceptives also containing progestin had the opposite effect, the effect of Depo-Provera was not attributed to progestin, and the study found no correlation between progestin levels and that effect-is to impermissibly draw grossly "overreaching conclusions," which are connected solely to the data by [the expert's] say-so. ${ }^{117}$

Finally, the court determined that the third step in the proposed mechanism was also unsupported because there was insufficient evidence to conclude that uterine contractions led to perforation by the embedded device. The court observed in analyzing the study upon which plaintiffs relied that "there were errors in the study's methods and findings." 118 While plaintiffs' expert attempted to use his "experience" to correct for these deficiencies, the court concluded that "[ $t]$ his does not rise to the level of intellectual rigor of medical or scientific study, rendering this opinion unreliable."119 Moreover, the court observed that plaintiffs' expert had essentially ignored literature showing that the hormone in Mirena "actually decreases the strength and frequency of uterine contractions," attempting to explain it away by arguing that because contractions "are not eliminated entirely, they still contribute to embedment." 120 The court concluded that such reasoning was unreliable because "[a]ny theory that fails to explain information that would otherwise tend to cast doubt on that theory is inherently suspect." 121

As illustrated above, the court was skeptical of steps in the analyses presented by the experts that were not supported by data (or which were counter to existing data). For example, the court noted that one of

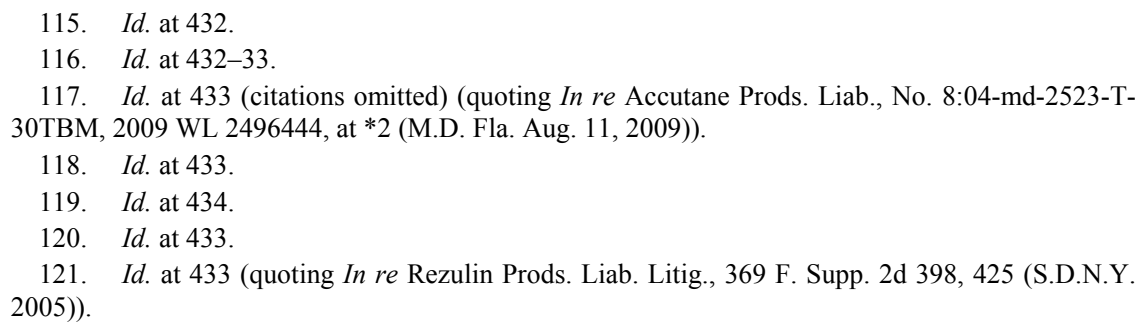


plaintiff's experts relied on studies of women not using Mirena or a similar progestin-releasing IUD for information on uterine contractions. ${ }^{122}$ While plaintiffs maintained that more specific data were not available, the court concluded that the expert's "lack of access to reliable data does not justify use of unreliable data, and militates against admission under Daubert." "23 Moreover, as plaintiffs' expert acknowledged, Mirena actually "reduces the force of uterine contractions," but the expert "ignored this inconvenient truth" in relying on studies that did not involve Mirena. ${ }^{124}$ The court concluded that "[a] legitimate scientist or engineer in the field, knowing he did not have reliable numbers for a stage of his analysis, would decline to reach a conclusion. [The expert's] proceeding when he knew he did not have the proper basis suggests that his 'methodology was aimed at achieving one result,' which is the sort of science Daubert does not allow." 125

The court also found that the experts' heavy reliance on animal studies was unreliable. As the court observed, the "reliance on animal studies, without a sound basis for extrapolating [those] studies to human uteruses, is another example where [the experts'] conclusions do not 'flow reliably from the premises." "126 The court noted that there were "just too many gaps between [the experts'] analysis and the conclusions" drawn from the evidence. $^{127}$

Finally, the court found significant the lack of support within the scientific community for plaintiffs' theories regarding secondary perforation, noting that they had not been "generally accepted in the scientific community." 28 As the court observed, "[t]extbooks on gynecology and leading organizations such as the World Health Organization ('WHO') and ACOG do not support [the experts'] opinions regarding secondary perforation." 129 The court noted that "[e]ven if there are some members of the medical and scientific community who agree that secondary perforation is a plausible way by which an IUD can perforate a uterus, Plaintiffs have not established general acceptance."130

\footnotetext{
122. Id. at 445 .

123. Id.

124. Id.

125. Id. (citation omitted) (quoting Faulkner v. Arista Records LLC, 46 F. Supp. 3d 365, 381 (S.D.N.Y. 2014)); see also id. at 449 (expert's "contention that it is 'undisputed' that secondary perforation occurs, without confronting scientific literature that refutes this notion, casts doubt upon the reliability of her opinions.").

126. Id. at 445 (quoting Rezulin, 369 F. Supp. 2d at 426).

127. Id.

128. Id. at $448-49$.

129. Id. at 449

130. Id. In addition to examining their methodology, the court also closely scrutinized the
} 
In a subsequent ruling on defendant's omnibus motion for summary judgment on hundreds of asserted claims, the court rejected plaintiffs' attempts to argue that they could bring their claims without reliable expert evidence establishing general causation. In a ruling, much like that of the court in Lipitor, the court rejected efforts to substitute purported "admissions" in company documents, labeling, or other materials for reliable scientific evidence of causation. ${ }^{131}$ Likewise, the court rejected plaintiffs' argument that the injuries at issue were simply soft tissue injuries that could be proven without expert testimony. As the court observed, "[t]here is no basis on which to conclude that it is within the ordinary experience and understanding of lay people that an IUD could spontaneously travel through or become embedded in an intact uterine wall." 132

The Mirena MDL is also significant because it illustrates how not only defendants, but also plaintiffs may seek to employ the MDL procedures to obtain rulings on common issues. In Mirena, plaintiffs sought to obtain rulings on the reliability of defendants' scientific theories, asserting that the defense experts' contention that there was no evidence of secondary perforation was unreliable. ${ }^{133}$ Accordingly, the Mirena litigation represents an example where plaintiffs also sought to utilize the MDL process to obtain guidance on issues that were common to the asserted cases, and specifically common issues relating to the reliability of proffered scientific evidence. Consistent with its rulings on plaintiffs' experts, however, the court for the most part rejected plaintiffs' contentions that the defendants' scientific evidence was somehow unreliable or unsupported. ${ }^{134}$

qualifications of plaintiffs' experts. For example, one of plaintiffs' proffered experts was a biomedical engineer who had no previous experience with IUDs or hormonal contraception like Mirena. The court concluded that the expert's engineering qualifications allowed him to testify about the "mechanism by which a Mirena might perforate a uterus, but he is not qualified to opine on the effects of [hormone contained in Mirena] on the uterus because he is not a medical doctor nor does he have relevant experience or expertise in hormonal contraception or the effects of hormones on uterine tissue." Id. at 439 (citation omitted). The fact that plaintiff's expert had reviewed some articles on the topic did not save his opinions. Id. ("This is not the level of rigor an expert in the field would apply and does not pass muster under Daubert."). Likewise, another expert sought to opine on the adequacy of Mirena's label even though she was a physiologist who acknowledged that she was not qualified to offer an opinion on pharmaceutical labeling in the United States. Id. at 448. Finding that she lacked the requisite qualifications, the court excluded her testimony in this area. Id.

131. In re Mirena IUD Prods. Liab. Litig., 202 F. Supp. 3d 304, 312, 314-320 (S.D.N.Y. 2016).

132. Id. at 312 . The court noted that, having excluded the proffered expert evidence, summary judgment was "compelled by the law." $I d$. at 328.

133. Mirena, 169 F. Supp. 3d at 419.

134. See id. at 413-27. Among other things, the court rejected plaintiffs' contention that defendants' experts' testimony should be excluded under Daubert "because it arguably contradicts statements made by [defendant's] employees." Id. at 426 . The court concluded that, at most, this was 


\section{B. Substantive Legal Issues}

In addition to questions regarding the reliability and admissibility of proffered scientific evidence, which have been central to many recent large-scale MDL proceedings, resolution of other substantive legal issues can also directly resolve large-scale litigation. Whether plaintiffs can bring certain substantive claims can also prove dispositive in multidistrict litigation.

\section{The Norplant MDL}

In the Norplant MDL, for example, the court granted summary judgment based on a substantive legal issue that cut across the asserted claims: the learned intermediary doctrine. ${ }^{135}$ The Norplant litigation involved claims asserting that the Norplant contraceptive failed to provide adequate warnings regarding side effects such as headaches, mood swings, depression, nausea and other miscellaneous ailments. ${ }^{136}$ Defendants argued that the warnings contained in the product labeling were adequate and that, accordingly, claims relating to the twenty-six primary side effects disclosed in the adverse events section of the labeling should be dismissed. ${ }^{137}$ Further, defendants maintained that there was no evidence linking any of the other alleged side effects that plaintiffs asserted to Norplant and thus they should be dismissed for lack of evidence establishing causation. ${ }^{138}$

Defendants filed motions for partial summary judgment as to these categories of claims. ${ }^{139}$ Defendants first argued that the labeling with respect to the twenty-six disclosed side effects barred plaintiffs' claims pursuant to the "learned intermediary doctrine." "Un "Under [this] doctrine, a drug 'manufacturer is excused from warning each patient who receives the product when the manufacturer properly warns the prescribing physician of the product's dangers." 141

\footnotetext{
a matter for cross-examination. Id. at 427.

135. In re Norplant Contraceptive Prods. Liab. Litig., 215 F. Supp. 2d 795, 798 (E.D. Tex. 2002) (granting summary judgment terminating claims of "nearly all remaining non-settling Plaintiffs" based in part on application of the learned intermediary doctrine), aff'd sub nom. White v. Wyeth Labs., 69 Fed. App'x 658 (5th Cir. 2003).

136. Id. at 800; In re Norplant Contraceptive Prods. Liab. Litig., 165 F.3d 374, 376 (5th Cir. 1999).

137. Norplant, 215 F. Supp. $2 \mathrm{~d}$ at 800 .

138. Id.

139. Id.

140. Id.

141. Id. at 803 (quoting Porterfield v. Ethicon, Inc., 183 F.3d 464, 467-68 (5th Cir. 1999)).
} 
Applying the doctrine, the court concluded that the claims relating to the twenty-six conditions contained in the labeling were barred. ${ }^{142}$ The court rejected plaintiffs' argument that the learned intermediary doctrine was inapplicable because defendants engaged in aggressive direct-toconsumer marketing and over-promotion. ${ }^{143}$ Likewise, the court rejected plaintiffs' contention that there was an exception to the learned intermediary doctrine for contraceptive drugs or for claims of misrepresentation and fraud. ${ }^{144}$

Defendants likewise moved for partial summary judgment with respect to claims they described as "exotic" claims that did not appear in the Norplant labeling. ${ }^{145}$ The court granted defendants' motion with respect to these conditions not disclosed in the labeling. ${ }^{146}$ Indeed, plaintiffs failed to submit any expert evidence supporting general causation with respect to these conditions. ${ }^{147}$

\section{The Meridia MDL}

In the Meridia pharmaceutical litigation, defendants similarly brought successful motions for summary judgment that essentially terminated the litigation based on the adequacy of the product's labeling. ${ }^{148}$ The Meridia litigation involved claims brought by patients who had taken an antiobesity medication that they alleged had caused high blood pressure and a variety of adverse cardiovascular and cerebrovascular events. ${ }^{149}$ The Judicial Panel on Multidistrict Litigation consolidated the litigation before the U.S. District Court for the Northern District of Ohio. ${ }^{150}$ After significant discovery and briefing on a consolidated basis, the court granted summary judgment as to all claims, finding that the drug's labeling adequately warned of potential increases in blood pressure and associated consequences. ${ }^{151}$ The court's ruling effectively ended the litigation on a nationwide basis, thereby achieving a global resolution.

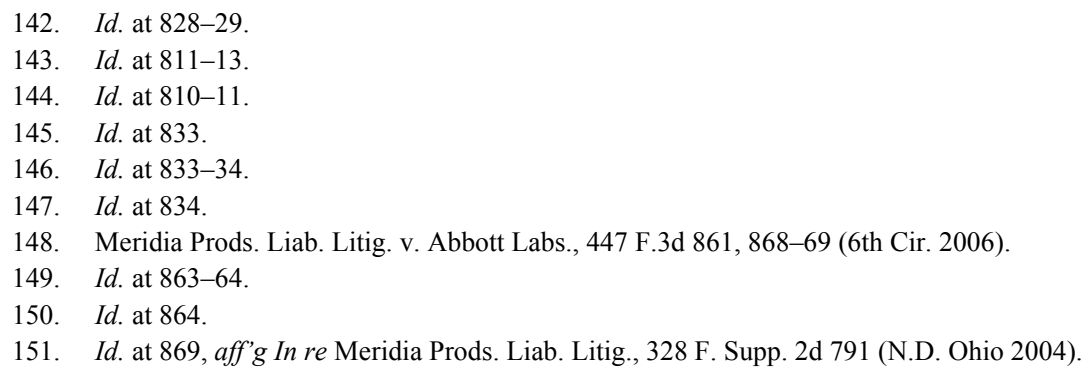


The MDL court observed that the labeling for Meridia specifically warned that patients could experience an increase in blood pressure. ${ }^{152}$ The court noted that "[p]hysicians are well aware of the scope of the risks associated with increased blood pressure and do not need specifics regarding the possible consequences of blood pressure increases." ${ }^{153}$ Accordingly, as the court reasoned, physicians would be aware that increases in blood pressure could lead to the sorts of cardiovascular or cerebrovascular events that plaintiffs claimed. ${ }^{154}$ Thus, the court concluded that the product warnings were adequate and granted summary judgment as to all asserted claims. ${ }^{155}$

\section{Preemption}

Defendants increasingly are raising preemption in a variety of contexts to bar claims brought by product liability plaintiffs. Preemption has been employed by medical device manufacturers to argue that some or all aspects of asserted product liability claims should be barred based on conflicts with federal statutes governing medical devices. ${ }^{156}$ It has also been employed successfully by pharmaceutical manufacturers to cut off state law product liability claims on the ground that they conflict with federal law regulating pharmaceuticals. ${ }^{157}$

The Fosamax MDL provides an illustration of how an MDL court applied the preemption doctrine to eliminate product liability claims brought against generic pharmaceutical manufacturers. The Fosamax litigation involved allegations that an osteoporosis medication increased the risk of long bone fractures. ${ }^{158}$ Plaintiffs sued not only the manufacturer of the branded drug, but also various companies that had made generic

\footnotetext{
152. In re Meridia, 328 F. Supp. $2 \mathrm{~d}$ at $812-13$.

153. Id. at 813 .

154. See id.

155. Id. at 815. The TMJ Implants Products Liability Litigation was another multidistrict proceeding whose outcome turned on common substantive issues. See In re Temporomandibular Joint (TMJ) Implants Prods. Liab. Litig., 97 F.3d 1050, 1055 (8th Cir. 1996) (granting motion for summary judgment brought by defendant suppliers of film incorporated into TMJ implants on the ground that "suppliers of inherently safe "component parts are not responsible for accidents that result when the parts are integrated into a larger system that the component part supplier did not design or build"” (quoting Sperry v. Bauermeister, Inc., 4 F.3d 596, 598 (8th Cir. 1993)).

156. See, e.g., Riegel v. Medtronic, Inc., 552 U.S. 312 (2008); Mink v. Smith \& Nephew, Inc., 860 F.3d 1319 (11th Cir. 2017); Caplinger v. Medtronic, Inc., 784 F.3d 1335 (10th Cir. 2015); In re Medtronic, Inc., Sprint Fidelis Leads Products Liab. Litig., 623 F.3d 1200 (8th Cir. 2010); Williams v. Cyberonics, Inc., 388 Fed. App'x 169 (3d. Cir. 2010).

157. See e.g., In re Fosamax (Alendronate Sodium) Prods. Liab. Litig. (No. II), 751 F.3d 150 (3d Cir. 2014).

158. Id. at 154
} 
versions. ${ }^{159}$ The generic manufacturers moved under Federal Rule of Civil Procedure 12(c) for judgment on the pleadings on the ground that plaintiffs' claims were preempted under federal law. ${ }^{160}$ They maintained that plaintiffs' contention that the manufacturers should have included different or additional warnings in their labels conflicted with federal law that precluded them from making changes to the labeling that were at odds with the labeling approved for the branded pharmaceutical product. ${ }^{161}$ They asserted therefore that plaintiffs' claims were preempted by the Supreme Court's ruling in Mensing. ${ }^{162}$

In Mensing, the Supreme Court held that FDA regulations applicable to generic drug manufacturers directly conflict with and therefore preempt state law failure-to-warn claims. ${ }^{163}$ As the Court observed, "when a party cannot satisfy its state duties without the Federal Government's special permission and assistance, which is dependent on the exercise of judgment by a federal agency, that party cannot independently satisfy those state duties for pre-emption purposes." 164

The generic defendants in Fosamax argued that the Supreme Court's decision in Mensing required that all state law claims arising from alleged defective labeling be dismissed because it was impossible to comply with both federal drug regulations and alleged state tort and statutory duties. ${ }^{165}$ The court agreed, noting that "Mensing stands for the principle that a federal duty of sameness arising out of FDA's regulatory requirements preempts any conflicting tort duty arising under state law." 166 As a result, the generic defendants could not alter the design of the pharmaceutical product or change their labels to provide different warnings because to do so would have violated federal law. ${ }^{167}$ Accordingly, the court granted defendants' motion for summary judgment, and the Third Circuit affirmed its decision. ${ }^{168}$

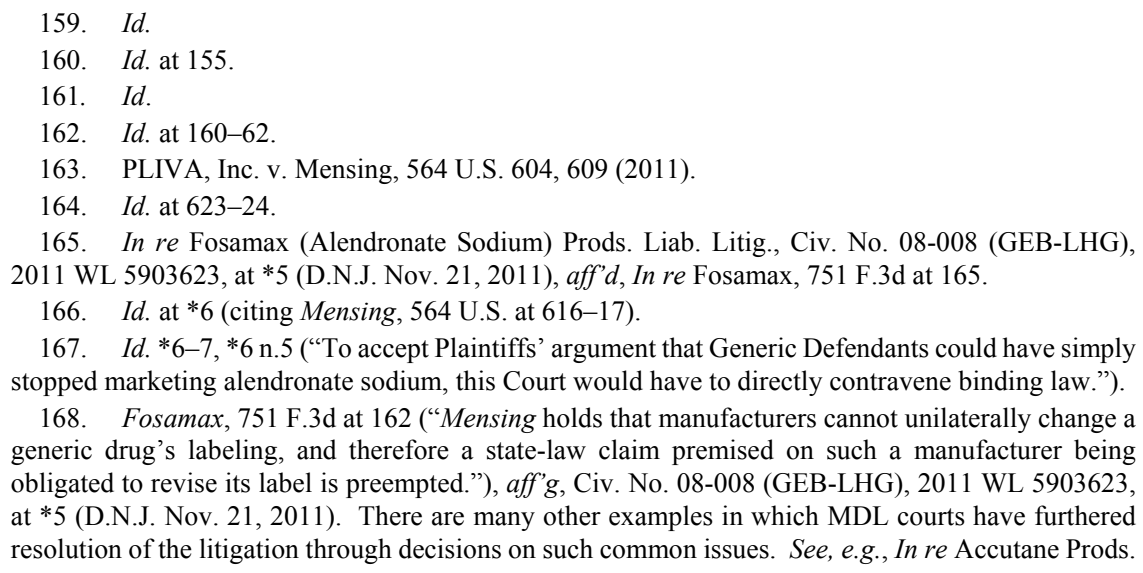
stopped marketing alendronate sodium, this Court would have to directly contravene binding law.").

168. Fosamax, 751 F.3d at 162 ("Mensing holds that manufacturers cannot unilaterally change a generic drug's labeling, and therefore a state-law claim premised on such a manufacturer being obligated to revise its label is preempted."), aff'g, Civ. No. 08-008 (GEB-LHG), 2011 WL 5903623, at *5 (D.N.J. Nov. 21, 2011). There are many other examples in which MDL courts have furthered resolution of the litigation through decisions on such common issues. See, e.g., In re Accutane Prods. 


\section{OBTAINING GREATER EFFICIENCY IN THE RESOLUTION OF COMMON ISSUES}

As these examples make clear, resolution of common issues is an important function of MDL proceedings. Moreover, numerous courts have successfully narrowed or resolved thousands of cases by addressing such issues in various ways. These examples illustrate that, despite the criticisms and the well-publicized examples in which the MDL process has failed, in many cases, the MDL process has worked as it was contemplated. The foregoing examples demonstrate that the MDL process can and has worked.

The lessons learned from MDL proceedings in which parties have litigated common issues illustrate a number of ways in which efficiency may be increased. First, it is not uncommon for there to be some level of state litigation that proceeds in parallel with federal MDL litigation. While defendants may attempt to remove state court cases to federal court and transfer them to the consolidated MDL proceedings, such efforts are not always completely successful. Accordingly, where such litigation exists, coordination between the state and federal MDL judges may lead to greater efficiencies.

Second, application of the framework developed by the Supreme Court in Daubert v. Merrell Dow Pharmaceuticals is often useful in narrowing or eliminating claims where plaintiffs have failed to offer expert evidence that is both relevant and reliable. Many of the examples cited above involve litigation of scientific issues under Rule 702 and Daubert, and the Supreme Court itself has repeatedly underscored that judicial scrutiny of proffered expert evidence is an important mechanism for eliminating claims that lack merit before trial. However, Daubert has sometimes been under-utilized. To the extent courts vigorously exercise their gatekeeping role under Rule 702, efficiencies are likely to be achieved.

Third, MDL courts have implemented effective scheduling procedures that closely track litigation of the various generic and case-specific issues and which can increase the efficient resolution of pending cases. For example, discovery and litigation of the various substantive issues may be phased in order to avoid unnecessary discovery and the associated expense and to streamline the proceedings. Such procedures can result in

Liab. Litig., 511 F. Supp. 2d 1288 (M.D. Fla. 2007) (excluding proposed expert testimony that acne medication was associated with inflammatory bowel disease as unreliable); In re Rezulin Prods. Liab. Litig., 369 F. Supp. 2d 398 (S.D.N.Y. 2005) (excluding proposed expert testimony that drug could cause or exacerbate liver injury "silently," without markedly elevating liver enzyme levels concurrently with use). 
significant gains in efficiency and cost savings.

Fourth, as noted above, a parallel track that gives scrutiny to individualized claims is important to further narrow and focus the litigation. There may be cases that cannot be disposed of by resolving common issues but nonetheless should not proceed. A process of individualized scrutiny and review therefore may be necessary in order to eliminate such claims.

Finally, to the extent bellwether trials are conducted, they should only be conducted after procedures for narrowing and winnowing the asserted claims have been implemented. Moreover, steps should be taken to ensure that any cases that are selected for bellwether trials are representative of the remaining population of claims.

\section{A. Coordination with State Courts}

The need to coordinate with state courts is a frequent concern in multidistrict litigation. In disputes that involve multiple related cases, it is not uncommon for cases to be filed in both state and federal court. While defendants frequently attempt to remove cases to federal court to consolidate them with ongoing MDL proceedings, they are not always successful in doing so. In such circumstances, federal MDL courts must give consideration to coordinating their proceedings with parallel state court proceedings. Sometimes there are similar mechanisms for consolidating cases within a state court system, ${ }^{169}$ but frequently cases are dispersed, and if cases are filed in more than one state there will be no mechanism available to consolidate among states.

There are many instances of coordination between MDL courts and state courts. The Manual for Complex Litigation notes, for example, that "[i]n scheduling Daubert proceedings in a dispersed mass tort case, an MDL judge should explore opportunities to coordinate scheduling with state courts handling parallel cases" and that "[f]ederal and state judges have successfully conducted joint Daubert hearings . ..."170 Likewise, the Federal Judicial Center has observed that "state judges have responded to requests for coordination in a spirit of cooperation." there is not this sort of close coordination, state courts typically take a back

169. ROTHSTEIN \& BORDEN, POCKET GUIDE, supra note 39, at 24 ("States increasingly have adopted procedures for assigning complex multiparty litigation to a single judge or judicial panel, or have created courts to deal with complex business cases.").

170. MANUAL FOR COMPLEX LITIGATION, supra note $21, \S 22.87$.

171. ROTHSTEIN \& BORDEN, POCKET GUIDE, supra note 39, at 24 ("The more transparent and even-handed the proposed cooperative venture is, the more acceptable it will be to other judges and to attorneys."). 
seat, allowing the federal MDL court to address these fundamental threshold issues.

\section{B. Application of Daubert Procedures}

The use of generic motion practice in situations where claims turn on disputed scientific evidence can be particularly valuable. As is illustrated in the above examples, MDL courts have frequently applied the framework developed by the Supreme Court and embodied in the Federal Rules of Evidence to determine the reliability of the scientific evidence supporting asserted claims. Such determinations have often been dispositive in resolving all, or some portion, of claims in products liability cases, for example.

In Daubert, the Supreme Court held that courts must serve as "gatekeepers" to ensure that "any and all scientific testimony or evidence admitted is not only relevant, but reliable." 172 In conducting such a review, "the trial court must scrutinize" the "principles and methods used by the expert," "173 and "must . . . exclude proffered scientific evidence . . . unless [it is] convinced [the evidence] speaks clearly and directly to an issue in dispute in the case, and that it will not mislead the jury." 174

The Supreme Court articulated a two-prong test to assist courts in assessing the admissibility of expert testimony. The party sponsoring the expert evidence has the burden to demonstrate that the requirements of Rule 702 are met. ${ }^{175}$ First, the expert testimony must "assist" the trier of fact, a condition that speaks "primarily to [the] relevance" of the proffered evidence. ${ }^{176}$ The Court characterized this requirement as one of "fit"that is, the expert testimony must be "relevant to the task at hand" in that it "logically advances a material aspect of the proposing party's case." Second, the "proposed testimony must be supported by appropriate validation" and be grounded "in the methods and procedures of

\footnotetext{
172. Daubert v. Merrell Dow Pharms., Inc., 509 U.S. 579, 589 (1993).

173. FED. R. EVID. 702 advisory committee's note to 2000 amendment.

174. Daubert v. Merrell Dow Pharms., Inc., 43 F.3d 1311, 1321 n.17 (9th Cir. 1995), remand from 509 U.S. 579.

175. See Pride v. BIC Corp., 218 F.3d 566, 578 (6th Cir. 2000) (“[A] party proffering expert testimony must show by a 'preponderance of proof' that the expert whose testimony is being offered is qualified and will testify to scientific knowledge that will assist the trier of fact in understanding and disposing of issues relevant to the case.") (citing Daubert, 509 U.S. at 592); Daubert, 43 F.3d at 1316 ("[T] $]$ he expert's bald assurance of validity is not enough. Rather, the party presenting the expert must show that the expert's findings are based on sound science, and this will require some objective, independent validation of the expert's methodology.").

176. Daubert, 509 U.S. at 580.

177. Daubert, 43 F. 3d at 1315 (citing Daubert, 509 U.S. at 591)
} 
science."178 In other words, the testimony must offer "more than subjective belief or unsupported speculation." 179 Under Daubert and Rule 702 , "[i]t is the proponent of the testimony that must establish its admissibility by a preponderance of proof."

In conducting this analysis, courts "evaluate the data offered to support an expert's bottom-line opinions to determine if that data provides adequate support to mark the expert's testimony as reliable."" "Scientific evidence and expert testimony must have a traceable, analytical basis in objective fact before it may be considered on summary judgment." 182

Mere "hypotheses," even if plausible and well founded, are insufficient to satisfy the Daubert test, for "a hypothesis is [simply] a scientist's educated speculation." 183 Similarly, Rule 702 bars expert testimony that is inconsistent with "the vast majority of the relevant, peer reviewed scientific literature." ${ }^{184}$ Under Rule 702 and Daubert, "any step that renders the analysis unreliable under the Daubert factors renders the expert's testimony inadmissible." 185

As the Supreme Court's decisions make clear, the Court views the Daubert framework as an important screen for assessing whether claims should proceed to trial. As Justice Breyer has observed, the failure of a trial court to provide adequate scrutiny to proffered scientific evidence can have significant adverse consequences:

[It is] particularly important to see that judges fulfill their Daubert gatekeeping function, so that they help assure that the powerful engine of tort liability, which can generate strong financial incentives to reduce, or to eliminate, production, points towards the right substances and does not destroy the wrong ones. It is, thus, essential in this science-related area that the courts administer the Federal Rules of Evidence in order to achieve the "end[s]" that the Rules themselves set forth, not only so that proceedings may be "justly determined," but also so "that the truth may be ascertained." 186

\footnotetext{
178. Daubert, 509 U.S. at 590.

179. Id.

180. Nelson v. Tenn. Gas Pipeline Co., 243 F.3d 244, 251 (6th Cir. 2001) (citing Daubert, 509 U.S. at 592 n.10).

181. United States v. 33.92356 Acres of Land, 585 F.3d 1, 7 (1st Cir. 2009) (quoting Ruiz-Troche v. Pepsi Cola of P.R. Bottling Co., 161 F.3d 77, 81 (1st Cir. 1998)).

182. Bragdon v. Abbott, 524 U.S. 624, 653 (1998) (citing Gen. Elec. Co. v. Joiner, 522 U.S. 136, 144-45, 146 (1997)).

183. Whiting v. Boston Edison Co., 891 F. Supp. 12, 25 n.56 (D. Mass. 1995) (quoting Johnston v. United States, 597 F. Supp. 374, 393-94 (D. Kan. 1984)).

184. Conde v. Velsicol Chem. Corp., 24 F.3d 809, 814 (6th Cir. 1994).

185. In re Paoli R.R. Yard PCB Litig., 35 F.3d 717, 745 (3d Cir. 1994)

186. Gen. Elec. Co. v. Joiner, 522 U.S. 136, 148-49 (Breyer, J., concurring) (emphasis added)
} 


\section{Scheduling and Discovery}

Greater efficiencies may also be achieved through careful consideration of case management. For example, it may be appropriate to establish a schedule providing for separate resolution of common issues early in the MDL proceedings. As noted above, the Manual for Complex Litigation specifically recommends such phasing of the litigation. ${ }^{187}$ Frequently, in MDL proceedings one of the first orders of business is the establishment of a case management order to govern scheduling and other issues. Such case management orders regularly provide a period for the filing and resolution of dispositive motions early in the proceedings. ${ }^{188}$

Such scheduling orders may increase efficiency by allowing the court to narrow the issues before it before proceeding with full-blown discovery or considering other matters. For example, in many MDL proceedings there are generic issues that may be dispositive of the entire litigation, and resolution of such issues early in the proceedings may render further

(quoting FED. R. EvID. 102). As Justice Breyer similarly observed in an introduction to the Federal Reference Manual on Scientific Evidence,

a decision wrongly granting compensation, although of immediate benefit to the plaintiff, can improperly force abandonment of the substance. Thus, if the decision is wrong, it will improperly deprive the public of what can be far more important benefits-those surrounding a drug that cures many while subjecting a few to less serious risk, for example.

The upshot is that we must search for law that reflects an understanding of the relevant underlying science....

Stephen Breyer, Introduction, in FedERAL REFERENCE MANUAL ON SCIENTIFIC EVIDENCE 1, 4 (Fed. Judicial Ctr., 3d ed. 2011) (emphasis added).

187. Manual FOR COMPlex Litigation, supra note 21, § 22.634. See also Rothstein et al., supra note 56, at 621, 629 (discussing case management order in PPA MDL litigation "split[ting] expert discovery into two distinct phases, with generic causation discovery to occur" first in anticipation of Daubert and summary judgment motions on generic issues, followed by "case-specific expert discovery").

188. Case Management Order No. 23, In re Zyprexa Prods. Liab. Litig., No. 04-MD-1596 (E.D.N.Y. Apr. 24, 2007), ECF No. 1243 (providing for Daubert and summary judgment motions thirty-eight months after initial MDL transfer order in a products liability action alleging personal injuries caused by over-promotion of schizophrenia drug); Case Management Order No. 22, In re Ortho Evra Prods. Liab. Litig., No. 1:06-40000 (N.D. Ohio MDL Dec. 6, 2007), ECF No. 186 (providing for dispositive motions twenty-three months after initial MDL transfer order in products liability litigation involving alleged increased risks of blood clots, strokes, heart attacks and other side effects associated with use of contraceptive patch); Rep. \& Rec. of Spec. Master as to Discovery Plan and Initial Scheduling Order, In re Avandia Mktg., Sales Pracs. \& Prods. Liab. Litig., No. 07-MD1871 (E.D. Pa. Sept. 11, 2008), ECF No. 204, adopted and approved by Pretrial Order No. 23, In re Avandia, No. 07-MD-1871 (E.D. Pa. Sept. 26, 2008), ECF No. 217 (providing for Daubert and summary judgment motions twenty-eight and twenty-nine months, respectively, from initial MDL transfer order in products liability litigation involving alleged increased risk of adverse cardiovascular events caused by diabetes medication); Case Management Order No. 96, In re Baycol Prods. Litig., No. 01-MD-01431 (D. Minn. Oct. 17, 2003), ECF 3679 (providing for Daubert and summary judgment motions twenty-seven and twenty-eight months, respectively, from initial MDL transfer order in products liability litigation involving alleged injuries suffered as a result of taking recalled anti-cholesterol medication). 
proceedings unnecessary. Frontloading consideration of such issues has obvious efficiencies for the litigation.

However, even where the common issues do not govern the outcome of all cases, efficiencies may still be gained by resolving generic issues up front. It may be that resolution of such issues will eliminate whole categories of claims or that the court's rulings may obviate the need for certain types of discovery, for example. Narrowing the proceedings at the earliest possible stage has obvious benefits in terms of increasing overall efficiencies.

Indeed, even where the court ultimately denies motions seeking to narrow the litigation, such proceedings may play a valuable role in educating the court regarding the common issues in the case at the outset. The court will then be familiar with issues at the heart of the proceedingsthe very common issues that form the basis for the MDL— before they are litigated through bellwether trials or otherwise. Thus, even if the issues prove inappropriate for resolution by motion, addressing such motions early in the case will have benefits in terms of furthering the efficient resolution of the proceedings.

Discovery may be phased in order to increase these efficiencies. Thus, for example, MDL courts presiding over pharmaceutical product liability cases have entered orders providing that discovery will be limited to general causation in the initial phase of the proceedings to allow the court to resolve this threshold issue before proceeding to other issues in the case. ${ }^{189}$ Likewise, it is typical for MDL courts in such cases to phase expert discovery so that expert discovery regarding generic issues proceeds before expert discovery on case-specific issues. ${ }^{190}$

189. See, e.g., Initial Case Management Scheduling Order re General Causation at 1-2, In re Incretin Mimetics Prods. Liab. Litig., No. 13-MD-2452 (S.D. Cal. Feb. 18, 2014), ECF 325 ("Plaintiffs will narrow all discovery related requests to issues involving general causation. As a result, initial discovery and document production will be limited to whether the requested information has some tendency in logic to prove or disprove whether Defendants' incretin mimetic drugs cause pancreatic cancer."); see also MANUAL FOR COMPLEX LITIGATION, supra note 21, $§ 11.422$ ("For effective discovery control, initial discovery should focus on matters-witnesses, documents, informationthat appear pivotal. As the litigation proceeds, this initial discovery may render other discovery unnecessary or provide leads for further necessary discovery.").

190. See, e.g., Case Management Order at 29, In re Welding Rod Prods. Liab. Litig., No. 03 17000 (N.D. Ohio Dec. 9, 2003), ECF No. 63 (dividing identification of experts into "Core Experts," defined as "each expert who is expected to offer testimony that is generally applicable in support of plaintiffs' position," and case specific experts, and requiring identification of Core Experts first); Pretrial Order No. 24, In re St. Jude Med., Inc., Silzone Heart Valves Prods. Liab. Litig., No. 01-MD1396, 2003 WL 21011310, at*1 (D. Minn. Apr. 11, 2003), 2003 WL 21011310, at*1 (setting different deadlines for disclosure of case specific and generic experts); Pretrial Order No. 73, In re Baycol, No. 01-MD-01431 (D. Minn. Apr. 16, 2003), ECF No. 3486 (setting separate schedule for "expert witnesses who will be offering opinions on issues of general applicability that will be relevant to the cases pending in this MDL (hereinafter 'generic experts')"); Final Pretrial Order at 10, In re 


\section{Individualized Scrutiny of Asserted Claims}

As noted above, a parallel track that provides individualized scrutiny to individual claims is important to further narrow the litigation and eliminate claims of dubious merit. ${ }^{191}$ This type of review may be accomplished in many ways. The least formal mechanism involves review by defense counsel to identify cases to plaintiffs' counsel as candidates for voluntary dismissal. In some cases, plaintiffs' counsel may agree to dismissal in order to avoid scrutiny of their claims by the court.

If this informal means of review fails, defendants can resort to individual motion practice. There may be cases that are obvious candidates for motion practice. Not only may bringing such motions result in streamlining the litigation by eliminating dubious cases that are the subject of such motions, but it can also provide guidance to the parties about individual cases that are not the subject of the motion. Once a defendant obtains a ruling that a particular type of individual case is not viable, informal cooperation among the parties can be used to voluntarily dismiss additional cases that the parties agree would fall within the scope of the ruling.

In order to employ such procedures, however, defendants and the court must be provided sufficient information regarding the asserted claims. As noted above, it is standard practice to require plaintiffs to produce individual fact sheets that provide important information regarding each asserted claim. ${ }^{192}$ Likewise, where personal injuries are alleged it is standard practice to require that plaintiffs produce their medical records so that the claims can be evaluated. Other basic documentary support may also be required, and as noted above the court may also consider implementing a Lone Pine order that dismisses claims where plaintiffs fail to comply. ${ }^{193}$

In addition, it is not uncommon to have additional discovery of individual claims. Such discovery is not only, at bottom, a defendant's right, but also may be beneficial in uncovering information that will allow the court to further narrow the field of claims that are actually at issue in order to reach a negotiated resolution. Accordingly, it is important that adequate information is produced in order to facilitate such procedures.

\footnotetext{
Phenylpropanolamine (PPA) Prods. Liab. Litig., No. 01-MD-1407 (W.D. Wash. Dec. 13, 2004) ("Expert discovery was divided into two main categories: generic experts (testifying regarding issues of general applicability, including general causation) and case specific experts (testifying on behalf of a specific plaintiff).").

191. See supra notes 40-52 and accompanying text.

192. See supra note 46 and accompanying text.

193. See supra note 47 and accompanying text.
} 
The experience from past MDLs demonstrates that there are many claims that are candidates for voluntary dismissal without even having to go through individualized motion practice. As the MDL court observed in the In re Mentor Corp. Obtape Transobturator Sling Products Liability Litigation, for example, plaintiffs' counsel had filed numerous claims that they "should have known" lacked any "good faith" basis because they were "clearly barred by the applicable statute of limitations," plaintiffs" counsel were "unable to identify a specific causation expert," or where "counsel threw in the towel and did not even bother to respond to [a] summary judgment motion."194 There, the court warned plaintiffs' counsel that if it were forced to decide summary judgment motions on cases that lack a good faith basis in the future, the court would issue show cause orders as to why sanctions should not be imposed. ${ }^{195}$

Similarly, in the federal asbestos product liability MDL, the court established procedures to facilitate individual review by placing each case on an individual scheduling order setting forth fixed deadlines for completion of discovery and filing of dispositive motions. ${ }^{196}$ The court utilized magistrates to assist with the processing of the massive number of cases filed in that proceeding. ${ }^{197}$ The court required, among other things, each plaintiff to submit medical reports based on "medically accepted principles and practices" along with a complete exposure history to support their claims or face dismissal. ${ }^{198}$ In response, some plaintiffs voluntarily dismissed their claims, while defendants challenged the compliance of other plaintiffs. ${ }^{199}$ Cases that were not voluntarily or involuntarily dismissed proceeded to discovery and summary judgment. ${ }^{200}$ The judge presiding over the litigation found that having a single court rule on summary judgment motions in the individual cases resulted in efficiency, given that the MDL court was very familiar with the nature of the litigation and the associated legal issues and its rulings "would provide

\footnotetext{
194. In re Mentor Corp. Obtape Transobturator Sling Prods. Liab. Litig., No. 4:08-MD-2004 (CDL), 2016 WL 4705827, at*1 (M.D. Ga. Sept. 7, 2016) (Mem.).

195. Id.

196. Robreno, supra note 50, at 127.

197. Id. at 128.

198. Id. at $137-38$

199. Id. at 140.

200. Id. at 141 .
} 
predictability and consistency." 201 With the aid of such procedures, the court was able to resolve nearly 200,000 cases. ${ }^{202}$

\section{E. Bellwether Trials, To The Extent Necessary Or Appropriate, Following Common Issues Motion Practice}

Typically, the goal of plaintiffs in large MDL proceedings is to aggregate as many claims as possible and drive toward settlement. ${ }^{203}$ Indeed, part of the reason that resolution of common issues through summary judgment and other proceedings is so critical in MDL litigation is that inherent in the litigation is an incentive to file claims of dubious merit. The aggregation that drives the efficiencies of MDL litigation comes with an associated cost: the possibility that aggregation will serve as a magnet for claims that lack merit.

Accordingly, plaintiffs' counsel typically seek to try selected "bellwether" cases as soon as possible in order to use the results of such trials to pressure defendants into global settlements. However, as demonstrated above, experience shows that the way to efficiently and equitably advance the resolution of MDL proceedings is to resolve common threshold issues through summary judgment on common issues. Bellwether trials do not necessarily say anything about the numerous claims that are part of an MDL proceeding that have little or no merit. Plaintiffs will studiously seek to avoid having such cases go to trial. Likewise, a steadfast defendant can always avoid any impact of a bellwether trial by refusing to capitulate if it believes that the case is not particularly representative of the cases that have been aggregated.

Indeed, some have criticized the practice of conducting bellwether trials as altogether outside of the authority of the MDL court. ${ }^{204}$ The

201. Id. at 141-43 ("The key to successful execution of the summary judgment procedure was the MDL court's adherence to a rigorous schedule for all cases. ... Setting a goal line for the MDL litigation, that is, the time for filing a motion for summary judgment, and thereafter deciding the motions promptly, provided encouragement to counsel to litigate the case diligently in the MDL or to settle.").

202. Id. at 180 (“' S ]ince 2006 , there have been 186,524 cases transferred to MDL-875 [and] [o]f those cases, 183,545 have been resolved ....").

203. See Bradt, supra note 1, at 791 ("[A]s several scholars have noted, like the class action, the key virtue of the MDL is that it collects most parties in a single organized proceeding in order to facilitate a global settlement."); Redish \& Karaba, supra note 51, at 111 ("MDL involves something of a cross between the Wild West, twentieth-century political smoke-filled rooms, and the Godfather movies."); id. at 128 ("Settlement is the fate of almost all cases that are part of an MDL. . . P Parties to MDL cases and the transferee judges who preside over them face tremendous pressure to settle.").

204. See, e.g., LAWYERS FOR CIVIL JUSTICE, REQUEST FOR RULEMAKING TO THE ADVISORY COMMITTEe ON CIVIL Rules 12 (Aug. 10, 2017), http://www.uscourts.gov/sites/default/files/17-cvrrrrr-suggestion_lcj_0.pdf ("The MDL statute provides for "coordinated or consolidated pretrial proceedings,' not trials. Despite the clear limit of this statutory authority, many MDL judges exercise 
statute references coordination of cases for the purposes of "pretrial proceedings." 205 The argument of these critics is that the statute does not authorize the MDL court to conduct actual trials of transferred cases.

In any event, the impact of the bellwether trial in an MDL proceeding is to some extent inherently limited. As a threshold matter, the bellwether trial can have no binding effect on any other case. The idea behind conducting such trials is that it will give the parties some measure of the value of the cases. ${ }^{206}$ As one group of commentators have observed, such proceedings may also help the parties to develop their approach to the case and put together "trial packages" that can be utilized in future individual trials. ${ }^{207}$ Moreover, the MDL court cannot compel a party to try any case that has been transferred to the court. Accordingly, aside from the potential in terrorem effect of a significant adverse trial outcome on a defendant (which itself can have a fairly significant practical effect), the actual power of the bellwether trial mechanism to advance the resolution of an MDL proceeding is limited.

To the extent that bellwether trials are part of an MDL proceeding, it is important to give consideration to factors that might increase their utility. For example, frequently there are disputes regarding the way cases are selected for trial. To the extent possible, one should seek to avoid bias and non-representativeness in the cases that are selected. ${ }^{208}$ Typically, courts employ procedures that allow both sides to select cases, frequently accompanied with strikes, so that the other side may eliminate cases that in its view are not appropriate trial candidates. ${ }^{209}$

the extraordinary power that inures to them by virtue of presiding over high stakes litigation to pressure parties to agree to a 'bellwether' or test trial." (footnote omitted)).

205. 28 U.S.C. $\S 1407$ (2012).

206. See Hon. Eldon E. Fallon et al., Bellwether Trials in Multidistrict Litigation, 82 Tul. L. REV. 2323, 2338 (2008) ("[B]ellwether trials can precipitate and inform settlement negotiations by indicating future trends, that is, by providing guidance on how similar claims may fare before subsequent juries.").

207. Id. at 2325 ("At a minimum, the bellwether process should lead to the creation of "trial packages' that can be utilized by local counsel upon dissolution of MDLs, a valuable by-product in its own right that supplies at least a partial justification for the traditional delay associated with MDL practice.").

208. Id. at 2326 (" [T] he transferee court must devise the appropriate methodology for selecting a predetermined number of individual cases from the pool for trial."). As one MDL judge has explained: "A bellwether trial is most effective when it can accurately inform future trends and effectuate an ultimate culmination to the litigation; therefore, it is imperative to know what types of cases comprise the MDL. Otherwise, the transferee court and the attorneys risk trying an anomalous case, thereby wasting substantial amounts of both time and money." Id. at 2344.

209. See id. at 2365 ("Regardless of which method is ultimately employed, a transferee court should consider allowing each side of coordinating attorneys to veto or strike from consideration a predetermined number of cases in the trial-selection pool. No matter how diligently the attorneys or the transferee court fill the trial-selection pool, the possibility will always remain that, after the close 
Another way to achieve "representativeness" is to couple the bellwether selection process with parallel proceedings described above that eliminate the cases that should not go to trial. Through omnibus summary judgment proceedings, discovery of all filed cases coupled with individual summary judgment proceedings, and informal mechanisms in which counsel voluntarily agree to dismiss claims of dubious merit, the population of cases in the MDL can be culled so that only cases that are more likely to be "representative" of trial-worthy cases remain. Accordingly, far from being the be-all and end-all of an MDL proceeding, the bellwether process - to the extent it is employed at all - can be a beneficiary of the more critical process of resolving issues during pretrial proceedings to separate the wheat from the chaff among the asserted claims.

\section{CONCLUSION}

Despite recent criticisms, multidistrict litigation procedures have been employed on multiple occasions to effectively and efficiently resolve complex litigation. The examples in which courts have successfully employed such procedures teach that it is critical to resolve common issues at an early stage in the litigation. Moreover, they further show that the efficiency of multidistrict proceedings can be enhanced by coupling litigation of common issues with individualized review of individual claims, coordination with parallel state court proceedings, rigorous application of Daubert standards governing the admissibility of expert evidence, and phasing discovery to avoid unnecessary delay and expense in resolving asserted claims.

While any set of procedures can benefit from reform, the record shows that courts have creatively and effectively employed existing procedures to resolve large and complex litigation. Moreover, MDL courts have many tools that could be more widely used to curb the potential for fraud and abuse. The tendency of aggregation to result in the filing of meritless claims can be overcome through individualized scrutiny of those claims through available procedures. It is up to the parties and the judiciary to ensure that they are employed. 